\title{
Exploring social-ecological trade-offs in fisheries using a coupled food web and human behavior model
}

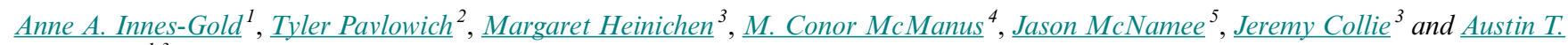
$\underline{\text { Humphries }}^{1,3}$

\begin{abstract}
Marine fisheries represent a social-ecological system driven by both complex ecological processes and human interactions. Ecosystem-based fisheries management requires an understanding of both the biological and social components, and management failure can occur when either are excluded. Despite the significance of both, most research has focused on characterizing biological uncertainty rather than on better understanding the impacts of human behavior because of the difficulty of incorporating human behavior into simulation models. In this study, we use the fisheries in Narragansett Bay (Rhode Island, USA) as a case study to demonstrate how coupled modeling can be used to represent interactions between the food web and fishers in a social-ecological system. Narragansett Bay holds both a commercial fishery for forage fish, i.e., Atlantic menhaden (Brevoortia tyrannus) and a recreational fishery for their predators, i.e. striped bass (Morone saxatilis) and bluefish (Pomatomus saltatrix). To explore trade-offs between these two fisheries, we created a food web model and then coupled it to a recreational fishers' behavior model, creating a dynamic socialecological representation of the ecosystem. Fish biomass was projected until 2030 in both the stand-alone food web model and the coupled social-ecological model, with results highlighting how the incorporation of fisher behavior in modeling can lead to changes in the ecosystem. We examined how model outputs varied in response to three attributes: (1) the forage fish commercial harvest scenario, (2) the predatory (piscivorous) fish abundance-catch relationship in the recreational fishery, and (3) the rate at which recreational fishers become discouraged (termed "satisfaction loss"). Higher commercial harvest of forage fish led to lower piscivorous fish biomass but had minimal effects on the number of piscivorous fish caught recreationally or recreational fisher satisfaction. Both the abundancecatch relationship and satisfaction loss rate had notable effects on the fish biomass, the number of fish caught recreationally, and recreational fisher satisfaction. Currently, the lack of spatial and location-specific fisher behavior data limits the predictive use of our model. However, our modeling framework shows that fisher behavior can be successfully incorporated into a coupled social-ecological model through the use of agent-based modeling, and our results highlight that its inclusion can influence ecosystem dynamics. Because fisher decision making and the ecosystem can influence one another, social responses to changing ecosystems should be explicitly integrated into ecosystem modeling to improve ecosystem-based fisheries management efforts.
\end{abstract}

Key Words: agent-based model; Ecopath with Ecosim; ecosystem-basedfisheries management; estuary; forage fish; social-ecological system

\section{INTRODUCTION}

Natural resource managers and policy makers are faced with how to sustain resources used in a coupled social-ecological system (Schlüter et al. 2012, Guerrero et al. 2018). These linked systems provide a variety of ecosystem services through a combination of natural components and social, economic, political, and cultural factors (Boyd and Banzhaf 2007). Managing these socialecological systems is difficult because of their adaptive, heterogeneous, multi-scaled, and time-varying nature (Liu et al. 2007). Marine fisheries are an important global industry representing the many qualities of a social-ecological system, which include complex environmental and ecological processes and a large human influence (Fulton et al. 2011). Achieving fisheries sustainability requires an understanding of the biological factors, i.e., fish stocks, as well as the social aspects, including coastal community livelihood and economic interest (Guerrero et al. 2018).

Fisheries science has strived to incorporate an understanding of the physical, biological, and ecological factors of an ecosystem, including the use of food web models that capture inter-species dynamics. Ecopath with Ecosim (EwE) is a food web model that simulates energy flow and biomass of organisms (Polovina 1984, Christensen and Pauly 1992). A guiding principle of EwE is energetic mass-balance, meaning that for each group in the model, the energy removed, i.e., predation or fishing, must be balanced by the energy consumed (Coll et al. 2009). The energy balance among groups is represented by two linear equations, corresponding to production and consumption. The static, energy-balanced food web snapshot of Ecopath is made temporally dynamic through Ecosim, which uses time series data and re-expresses these linear equations as time-varying differential equations. Through Ecosim, users can simulate how the food web responds to variations in drivers such as fishing mortality or primary production (Coll et al. 2009, Heymans et al. 2016). EwE is widely used for evaluating the ecosystem impacts of fisheries (Pauly et al. 2000). For example, Buchheister et al. (2017) used EwE to simulate different Atlantic menhaden (Brevoortia tyrannus) harvest levels along the U.S. East Coast and found that of their predators, Atlantic striped bass (Morone saxatilis) were the most sensitive to these changes. In fact, when menhaden were fished at maximum sustainable yield, striped bass

\footnotetext{
${ }^{1}$ Department of Fisheries, Animal and Veterinary Sciences, University of Rhode Island, Kingston, Rhode Island, ${ }^{2}$ AIS Inc. in support of the Northeast Fisheries Science Center, Narragansett, Rhode Island, ${ }^{3}$ Graduate School of Oceanography, University of Rhode Island, Narragansett, Rhode Island, ${ }^{4}$ Rhode Island Department of Environmental Management, Division of Marine Fisheries, Jamestown, Rhode Island, ${ }^{5}$ Rhode Island Department of Environmental Management, Bureau of Natural Resources, Providence, Rhode Island
} 
Fig. 1. Conceptual diagram of our social-ecological model, consisting of the Ecopath with Ecosim (EwE) food web model and the agent-based fisher behavior model. ABM = agent-based model.

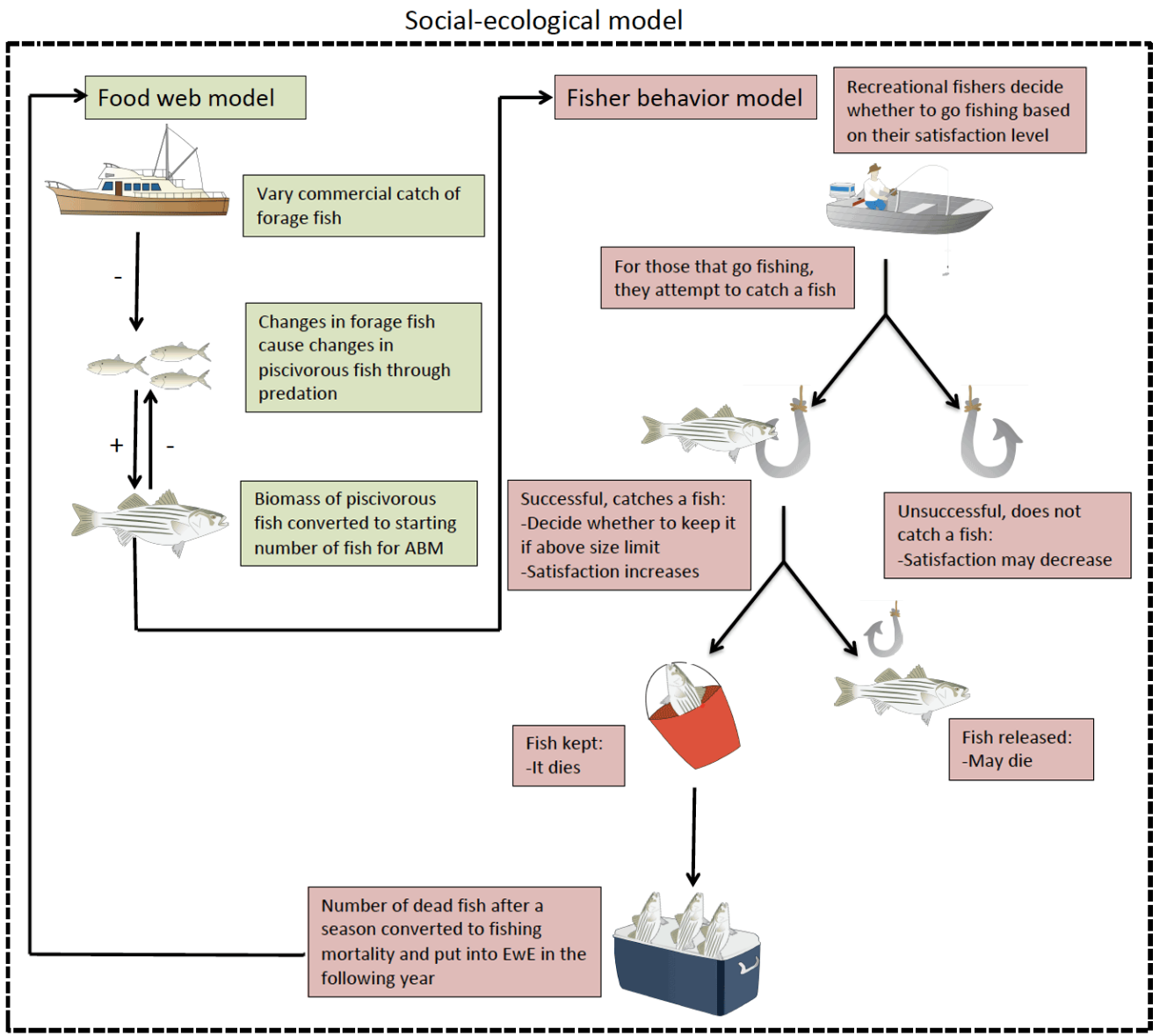

yield and biomass were predicted to decline by $\sim 60 \%$ (Buchheister et al. 2017). Although EwE can simulate changes in fishing effort, it does not have a way to include feedbacks from dynamic fisher behavior.

Management failure often occurs when fisheries are managed solely based on single-species needs and the social context is ignored (Cooper and Jarre 2017). In particular, human behavior has been identified as a large source of uncertainty in fisheries science and ecosystem-based fisheries management given that resource-users frequently behave differently than the expectations of managers and economic theory (Fulton et al. 2011). In a coupled social-ecological system, this uncertainty can compound through linkages between systems, creating an unreliable model (Cenek and Franklin 2017). A great deal of research continues to focus on increasing ecological knowledge despite the need to incorporate social and economic objectives. The push to account for human behavior in fisheries management has led to its inclusion in some recent modeling efforts (Ono et al. 2017, Matsumura et al. 2019, Kaemingk et al. 2020). Agent-based modeling (ABM) is a promising method for representing human behavior and is well-suited for ecosystem-based fisheries management (Burgess et al. 2020). In ABMs, a set of rules governs how autonomous "agents," e.g., individual people or fishing boats, interact with each other and the modeled environment (Macal and North 2005). ABMs are especially useful in resourceextraction systems, like fisheries, where heterogeneity exists both in the agents and the environment itself (Nolan et al. 2009). Although a useful tool, the use of ABMs in fisheries science and economics is underutilized (Cooper and Jarre 2017).

The overall objective of this study was to develop a coupled socialecological model to understand the extent to which the inclusion of fisher dynamics impacts ecological outcomes. Specifically, we study how our model projections respond to three factors that have the potential to affect social-ecological interactions: (1) changes in commercial fisheries harvest, (2) changes in the likelihood of catch in the recreational fishery, and (3) the rate at which recreational fishers become discouraged and change their behavior. Response variables include fish biomass, the number of fish caught by the recreational fishery, and recreational fisher satisfaction at the end of a season. To do this, we create an agentbased model of recreational fisher and fish dynamics (hereafter referred to as the "fisher behavior model") and couple it with an EwE model (hereafter referred to as the "food web model"; Fig. 1). To our knowledge, this is the first attempt at linking these types 
of models despite each being established research tools. We run the coupled EwE-ABM model (hereafter referred to as the "social-ecological model") under different scenarios and describe differences between model runs. In this work, we forecast organism biomass under various scenarios to demonstrate the use of our model. However, there is currently a lack of quantitative data on fisher behavior parameters, and thus we tested a range of assumed values. Therefore, our goal is not to predict how fish biomass in Narragansett Bay will change over time. Instead, we demonstrate a framework to link two established modeling methods and show how including the dynamics of human decision making can alter model forecasts and thus impact management.

\section{METHODS}

\section{Study site and context}

Narragansett Bay (Rhode Island, U.S.) has a long history of fishing as well as data collection. The first quantitative fisheries data in Narragansett Bay were collected in the late 1800s because of conflict between trap and hook-and-line fishers, who claimed that fish stocks were declining (Oviatt et al. 2003). These early records indicated that catch was dominated by anadromous species (alewife [Alosa pseudoharengus], American shad [Alosa sapidissima], rainbow smelt [Osmerus mordax]), boreal species such as winter flounder (Pseudopleuronectes americanus), and migratory species like Atlantic menhaden. These previously dominant species declined in the late 20th century (Oviatt et al. 2003), corresponding to shifts in environmental conditions and species community compositions, with warm-water species including scup (Stenotomus chrysops) and butterfish (Peprilus triacanthus) becoming common (Collie et al. 2008). Today, the fishing industry supports a significant portion of the Rhode Island economy. In 2016, the Rhode Island commercial seafood industry had a total economic output of $\$ 419$ million and supported over 4000 jobs (Mercer and Sproul 2018). The recreational fishery also plays a large economic role, accounting for $\$ 412$ million in sales, $\$ 176$ million in income, and supporting over 4000 jobs in 2016 (National Marine Fisheries Service 2018). Recreational boaters, including fishers, compose close to two thirds of all users in upper Narragansett Bay (Dalton et al. 2010).

The fisheries of Narragansett Bay provide a case study to explore fisheries trade-offs in a coupled social-ecological system. The commercial fishery that targets forage fish such as Atlantic menhaden operates primarily in the mid and upper Bay in areas of Greenwich Bay, Bristol Harbor, and Mount Hope Bay (Fig. 2). In addition to being commercial fishing targets, forage fish play an important role in the Narragansett Bay food web; they are the conduit of energy between the lower trophic level planktonic species and the upper trophic level predators, like piscivorous fishes, sea birds, and marine mammals (Innes-Gold et al. 2020). Because of this linkage, forage fish are important to the Narragansett Bay recreational fishery as a major food source for the targeted predator species. These predators, including striped bass and bluefish (Pomatomus saltatrix), are economically and socially valuable as popular recreational fishing targets (data query from the National Marine Fisheries Service, Fisheries Statistics Division). Although forage fish abundance is highly variable because of recruitment dynamics, overfishing can exacerbate these fluctuations and result in overfished populations with widespread ecosystem effects, particularly on forage fish predators (Essington et al. 2015). Conversely, exploitation of predators through fishing has been shown to cascade down and affect forage fish population dynamics (Engelhard et al. 2014).

Fig. 2. (A) The location of Narragansett Bay, RI relative to the Northeast United States and (B) the distribution of forage fish commercial fishing in Narragansett Bay.

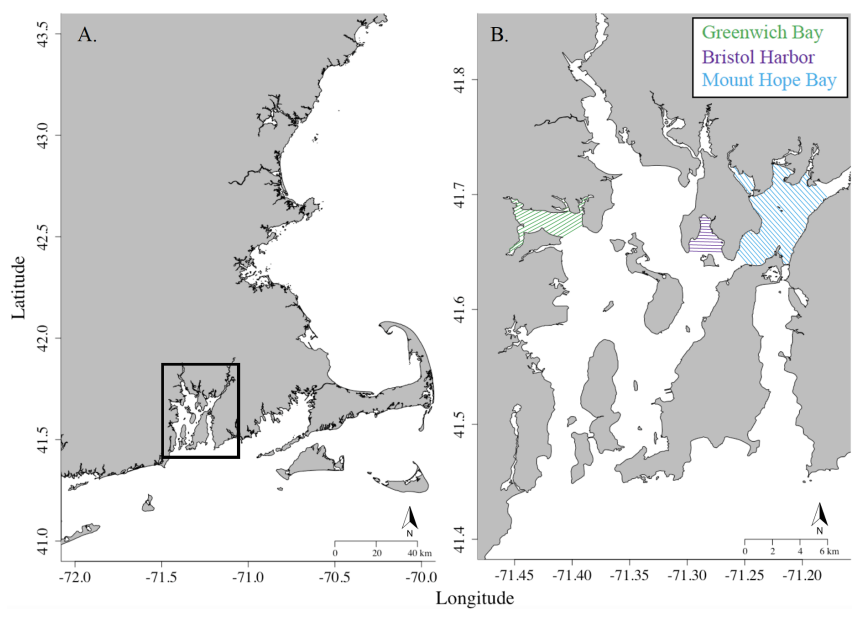

The trade-off between the role of forage fish as supporting a directed commercial fishery and providing the food base for recreationally targeted piscivorous fish poses a complex challenge for management, which is not unique to Narragansett Bay. Along the entire U.S. East Coast (Buchheister et al. 2017) and globally (Houle et al. 2013), the question of how harvesting prey and their predators affect one another, and how overall harvest should be managed in this context, has been studied and debated at length (Kuffner 2017, Chase 2019). Although this question has been explored for broader geographic ranges, Narragansett Bay has distinctly different dynamics given that it is an estuarine nursery ground for many fish species (Meng et al. 2002, Mateo et al. 2011). Additionally, these past studies have not explicitly incorporated how fisher behavior may change in response to shifts in the food web. Currently, fisheries managers in Narragansett Bay are faced with evaluating how forage fish harvest directly impacts the species' population dynamics and the recreational fisheries they support, without the proper tools to do so.

\section{Food web model}

The Narragansett Bay food web model was created using EwE (Innes-Gold et al. 2020). The mid and upper trophic level functional groups were piscivorous fish, forage fish, benthivorous fish, carnivorous benthos, squid, suspension feeding benthos, cultured shellfish, and seabirds. The lower trophic level functional groups were deposit feeding benthos, gelatinous zooplankton, zooplankton, phytoplankton, benthic algae, and detritus. The commercial and recreational fisheries were also represented. In this study, we were primarily interested in the forage fish (Atlantic menhaden, alewife, Atlantic herring [Clupea harengus], blueback herring [Alosa aestivalis], bay anchovy [Anchoa mitchilli], Atlantic moonfish [Selene setapinnis]) and the piscivorous fish (Striped 
bass, bluefish, summer flounder [Paralichthys dentatus], weakfish [Cynoscion regalis], spiny dogfish [Squalus acanthias]) functional groups. Functional group biomass data for the food web model were primarily informed by the University of Rhode Island Graduate School of Oceanography or Rhode Island Department of Environmental Management bottom trawl surveys. Production / Biomass $(\mathrm{P} / \mathrm{B})$ values were calculated as $\mathrm{Z}$, total mortality, the sum of natural and fishing mortality. Consumption / Biomass $(\mathrm{Q} / \mathrm{B}$ ) values primarily came from Fishbase (Froese and Pauly 2019) and Thomas-Brey's invertebrate consumption equations (http://www.thomas-brey.de/science/virtualhandbook/ navlog/index.html). Ecotrophic efficiency (EE) cannot be measured in the field and thus was solved for by Ecopath using a linear equation for all groups (Christensen et al. 2005). Recreational fishery landings came from the U.S. National Oceanic and Atmospheric Administration's (NOAA) National Marine Fisheries Service query tool (https://www.st.nmfs.noaa. gov/st1/recreational/queries/), and commercial landings were either estimated from a data request for NOAA Vessel Trip Reports or scaled down from Rhode Island state landings (https:// www.accsp.org/). Diet data were sourced from a variety of literature and data collection methods. The forcing functions used in the food web model were phytoplankton biomass $\left(\mathrm{g} / \mathrm{m}^{2}\right)$, cultured shellfish biomass $\left(\mathrm{g} / \mathrm{m}^{2}\right)$, and fishing mortality $(\mathrm{F}$; estimated as catch / biomass as recommended by Christensen et al. 2005, Heymans et al. 2016) for functional groups targeted by fisheries. See Innes-Gold et al. (2020) for further details on model inputs and data sources.

\section{Fisher behavior model}

We have created a fisher behavior ABM based on the piscivorous fish recreational fishery of Narragansett Bay using NetLogo (Wilensky 1999). Although we refer to this ABM as the "fisher behavior model," it includes both recreational fisher and fish population dynamics, detailed below. Our fisher behavior ABM used the overview, design concept, and details protocol (Grimm et al. 2006, 2010, 2020).

\section{Purpose and patterns}

The goal of this model is to create a dynamic representation of the Narragansett Bay recreational fishery to be linked to the food web model and examine the impact of fisher behavioral components on model projections. We will use this coupled socialecological model to quantify how the commercial harvest of forage fish, the abundance-catch relationship, and fisher satisfaction loss rate influence fish biomass, the amount of piscivorous fish caught by recreational fishers, and their satisfaction.

\section{Entities, state variables, and scales}

The first type of agent is a fish. In order to represent fish population dynamics, fish agents were assigned several attributes. Attributes included age, length, reproductive status (all start as "ready to spawn" and after spawning change to "not ready to spawn" for the remainder of the year), and sex (assuming a 1:1 sex ratio; Terceiro 2010, Sharov et al. 2013). Values were sourced from data on striped bass, bluefish, and summer flounder, the three most common recreational fishing targets included in the piscivorous fish functional group. It was necessary to include these stock characteristics so that the fish population was able to recover and sustain itself, rather than continuously decline as fishing occurred. Because these values were not easily obtained from the EwE model, they were sourced from literature. Two types or "breeds" of recreational fisheries were represented in the fisher behavior model: shore fishers and boat fishers. Fishers can have varied satisfaction levels, ranging from 2 to 10 (Shafer 2007), which dictates their participation in the fishery. This model represented the entirety of Narragansett Bay, with no further spatial components.

\section{Process overview}

Each time step was one week. Weeks 1-26 were "open season" for recreational fishing, representing May-October, and weeks 27-52 are "closed season," representing the rest of the year. This assumes that recreational fishing takes place in half the year. At each weekly time step, some fish agents first die because of natural mortality. Fish also reproduce, grow, and age. Shore and boat fishers decide if they will go fishing based on their satisfaction level. The active fishers then attempt to catch a fish. If they are successful at catching a fish, they decide whether to keep or release the fish. Fisher satisfaction increases if a fish is caught and decreases if an active fisher catches nothing, making them less likely to become active and fish the following week. The model then goes on to the next weekly time step.

\section{Design concepts}

Emergence: Fish population dynamics are sustained over the course of a model run by having each individual fish age, grow, reproduce, and die because of natural mortality and fishing mortality at each weekly time step. This maintains the overall population structure.

Adaptation: A fisher adapts based on its fishing success of previous time steps. If successful, the fisher becomes more likely to fish again at the subsequent time step.

Stochasticity: We have represented the following processes as stochastic probabilities: fish natural mortality, release mortality, a fisher's decision to fish, likelihood of catch, and likelihood of keeping a fish.

Observation: We observe the number of fish caught and kept, as well as the number remaining in the population at the end of a season. We also note the average fisher satisfaction at the end of each season.

\section{Initialization and input data}

Initial fish population sizes were calculated by converting the food web model-projected piscivorous fish biomass in 2019, which differed on the commercial harvest scenario, to a count of fish (Table 1). To do this, the $\mathrm{g} / \mathrm{m}^{2}$ biomass was converted into a total biomass for the whole Bay by multiplying the value by the area of the Bay (380 km²; Narragansett Bay Estuary Program 2017). This total biomass was then divided into different portions representing the different fish size classes (Table A1.1, estimated using striped bass data from NJ Division of Fish \& Wildlife 2010, Sharov et al. 2013). The average length of the fish in each size class was converted to a weight using a published striped bass length-weight equation (Kimmerer et al. 2005). The total biomass of fish in each size class was divided by the weight of an individual in that size class to get an approximate number of fish in that size class that are in the Bay. These size class count totals were summed to get an overall total number of fish and transformed by scaling values down by a factor of 1000 for runs in NetLogo. The 
inclusion of a size/age-structured population allowed for fish to have size-specific growth rates and age-specific mortality rates, which is particularly important for a size driven recreational fishery.

Table 1. The four scenarios of commercial forage fish harvest, the resulting 2020 piscivorous fish biomass, and the starting number of fish for the fisher behavior model (converted from the piscivorous fish biomass and divided by a factor of 1000).

\begin{tabular}{lcc}
\hline \hline $\begin{array}{l}\text { Commercial Harvest } \\
\text { Scenario }\end{array}$ & $\begin{array}{c}\text { 2020 Piscivorous fish } \\
\text { biomass } \\
\left(\mathrm{g} / \mathrm{m}^{2}\right)\end{array}$ & $\begin{array}{c}\text { Starting number of fish } \\
\text { for the fisher behavior } \\
\text { model }\end{array}$ \\
\hline Zero $(\mathrm{F}=0)$ & 9.39 & 15,100 \\
Status Quo $(\mathrm{F}=0.202)$ & 9.26 & 15,000 \\
Intermediate $(\mathrm{F}=1.68)$ & 8.50 & 13,700 \\
Extreme $(\mathrm{F}=3.167)$ & 8.01 & 12,900 \\
\hline
\end{tabular}

Individual fish's lengths (inches) were set using a random draw from a Poisson distribution. Forty percent of the fish population was drawn from a Poisson distribution with a mean of five inches, $30 \%$ from a mean of 10 inches, and $30 \%$ from a mean of 25 inches, done to approximately resemble published length distributions (NJ Division of Fish \& Wildlife 2010, Sharov et al. 2013). The fish age attribute was calculated from their assigned length using the Von Bertalanffy equation (Equation 1), where $\mathrm{k}$ is a growth coefficient that represents the rate at which L infinity, or the asymptotic maximum length (hereafter $\mathrm{L}_{\text {inf }}$ ), is approached (Froese and Pauly 2019). For our fish agents, k was set to 0.2 and $\mathrm{L}_{\text {inf }}$ to 50 inches.

$$
\text { Age }=\frac{-52}{k} \ln \left(1-\frac{\text { inches }}{L_{\text {inf }}}\right)
$$

For all trials, each fisher's satisfaction was assigned by randomly drawing from a normal distribution with a mean of five (SD = 1), assuming that there is some variation in the satisfaction levels of fishers and that the majority of fishers start off with an intermediate satisfaction level (Arlinghaus 2006, Pascoe et al. 2015). Initial participant total for each breed of fisher was based on the number of annual recreational fishing trips in Rhode Island from 2018 converted to weekly participation assuming all fishing took place in six months of the year (data query from the National Marine Fisheries Service, Fisheries Statistics Division). The resulting numbers were 35,000 shore and 9000 boat fishing trips per week, scaled down by a factor of 1000 to 35 and nine, respectively. The same starting number of fish and fishers were used for each model run.

\section{Submodels}

1. Natural mortality: There is age-dependent natural mortality. As a fish ages, the probability of dying by natural mortality decreases. The weekly natural mortality estimates used were 0.041 (age zero), 0.022 (age one), 0.004 (age two), 0.003 (age three), 0.001 (age four and up). Fish have a maximum lifespan of 21 years.

2. Somatic growth and maturation: Fish grow according to the Von Bertalanffy growth equation (Equation 2). $\mathrm{L}_{\text {inf }}$ was set to 50 inches, and $\mathrm{k}$ was set to 0.2 . Fish age +1 week at each time step.

$$
\text { Inches }=L_{\text {inf }}\left(1-\exp \left(\frac{k}{52} \text { age }\right)\right)
$$

1. Reproduction: An age 5+ female fish can spawn once per season (NOAA Fisheries 2020a, b, c). To allow for some density dependence, a female fish spawns 12 recruits if the fish population is $<5000$, seven recruits if the population is $5000-15,000$, and three recruits of the population is $>$ 15,000 .

2. Fishing activity: If a random number generated between 1 and 10 is less than a fisher's satisfaction level, then they become "active" and will go fishing. Because the minimum satisfaction value is two, there is always a chance a fisher will become active, but a lower satisfaction level means less likely to fish.

3. Deciding to keep or release a fish: If a fisher catches a keeper size fish, known as a keeper, (28-35 inches, current striped bass regulations in RI; Rhode Island DEM 2020), a 0.85 probability was set for the fisher to retain the fish, and a 0.15 probability that they will release it. If they catch a sublegal fish, they release it.

4. Release mortality: Released keepers and sublegal fish have a $7 \%$ and $10 \%$ chance of dying upon release, respectively (in range of species-specific studies: Diodati and Richards 1996, Lucy and Holton 1998, Malchoff and Lucy 1998, Nelson 1998, Atlantic States Marine Fisheries Commission 2015).

5. Abundance-catch relationship: The likelihood of a fisher catching a fish varied depending on the abundance of fish. In this study, we ran versions of the fisher behavior model with three different types of catch-abundance relationship: (1) a power function, (2) a linear relationship, (3) a static percentage (Fig. 3). The relationship between the probability of capturing a fish from shore or land is defined first as a power function (Equation 3, from Gaertner and DreyfusLeon 2004). We created four separate power functions for the probability of a fisher catching a sublegal fish from a boat, a sublegal fish from shore, a keeper from a boat, and a keeper from shore (Table A1.2).

$$
U_{t}=q A_{t}^{b}
$$

In this power function (Equation 3), $U_{t}$ is catch per unit effort (CPUE) at time t, $q$ is catchability, $A_{t}$ is abundance at time t, and $b$ is the shape parameter. $b$ was solved for after other parameters were entered (values used can be found in Table A1.2). For $U_{t}$, we used Marine Recreational Information Program data for recreational fishing trips, selecting "Inland Rhode Island" as our area of interest (https://www.st.nmfs.noaa.gov/st1/recreational/ MRIP Survey Data/). The number of shore or boat trips that caught one or more piscivorous fish (striped bass, bluefish, summer flounder) was divided by the total number of trips in the year to calculate a percent of trips that were successful in catching a keeper. The number of shore or boat trips that released one or more of these piscivorous fish was divided by the total number of trips in the year to calculate a percent of trips that were successful in catching a sublegal fish, assuming all released fish were of sublegal size. For keepers and sublegal fish caught from 
boats, data from the year 2017 was used. For keepers and sublegal fish caught from shore, recent years had very low success rates, creating a function that plateaued at a very low rate, and therefore an average of the success rates in the past 25 years was used. For keepers, catchability $(q)$ was set at 0.04 for boats and 0.02 from shore. For sublegal fish, $q$ was set at 0.08 for boats and 0.04 for shore. These values were derived from catchability work on the smallmouth (Micropterus dolomieu) and largemouth bass (Micropterus salmoides) in hook and line recreational fishery, which were the best available data for hook and line fishing (Hangsleben et al. 2013, Wildenhain 2016, Hansen 2018). Abundance at time $\mathrm{t}\left(A_{t}\right)$ was calculated by converting a piscivorous fish biomass (taken from the food web model time series) in 2017 to legal and sublegal fish counts using the methods described above for calculating the starting number of fish. We then solved for the shape parameter. We chose to run trials with a power functions because they are regularly used to understand how observed catch relates to species abundances (Hilborn 1985, Gaertner and Dreyfus-Leon 2004).

Fig. 3. The three types of abundance-catch relationships tested, split by fish size (keeper or sublegal) and method of fishing (boat or shore).
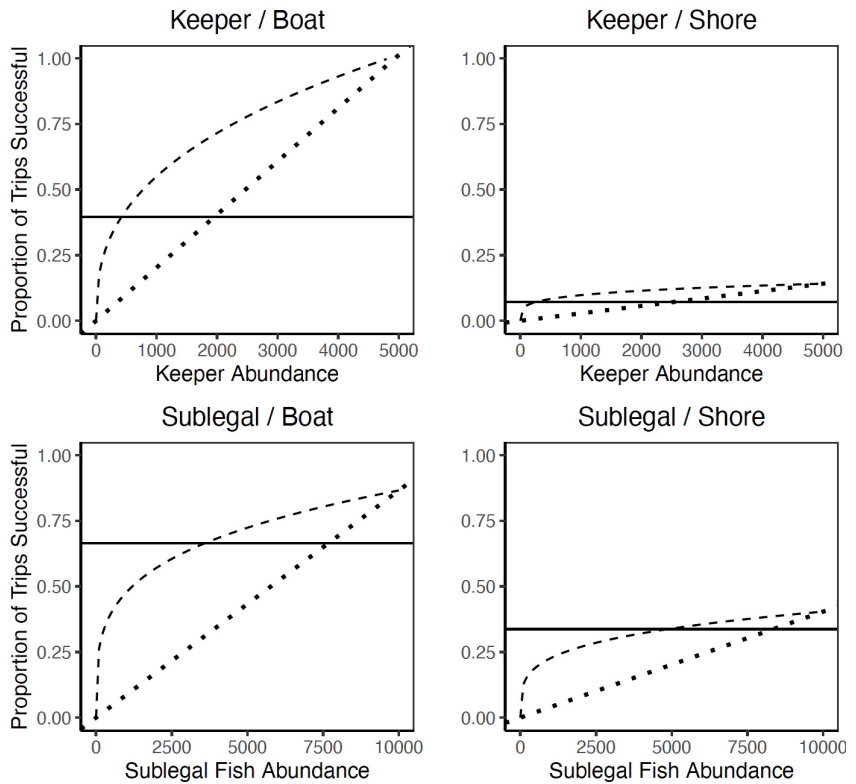

$$
\text { Relationship } \because \therefore \text { Linear },->\text { Power } \not \text { Static }
$$

Linear relationships have also been used to relate abundance and catch (Paloheimo and Dickie 1964, Campbell 2004). Four variations of the linear functions were created for catching sublegal fish and keepers from boat or shore methods (Table A1.2). The linear abundance-catch relationships for catching keepers and sublegal fish were created by defining a slope between the origin and the point of high fish abundance where the power curve began to plateau approaching a maximum point, meaning the catch rate was no longer increasing (5000 keepers, 10,000 sublegal fish). Finally, the static percentage abundance-catch relationship was set at the average percent of trips that were successful over the past 25 years, calculated from the Marine Recreational Information Program data (Table A1.2). A trip was classified as successful using the method described in the power function section.

1. Satisfaction loss rate: The rate at which fishers become discouraged if they have an unsuccessful fishing trip, i.e., zero catch, which we have termed "satisfaction loss," directly determines how likely the fisher is to continue fishing. We ran three different versions of the fisher behavior model to test how sensitive model results are to the rate of satisfaction loss. The three levels of satisfaction loss were one, half, and zero points lost at each week an active fisher catches nothing. In all trials, satisfaction increases by 0.1 points if a sublegal fish is caught and increases by one point when a keeper size fish is caught because recreational fishers have been shown to have increased satisfaction when they catch more fish (Pitman et al. 2019).

\section{Model calibration}

We set several model parameters so that the population would remain stable in the absence of fishing. When available, we started with parameter values from previous studies on striped bass, bluefish, and/or summer flounder, then made incremental adjustments until the population neither declined to zero nor increased to infinity and matched the observed size distribution (NJ Division of Fish \& Wildlife 2010, Sharov et al. 2013) as well as possible. In our model, the number of recruits per spawner ranged from 3 to 12, depending on the abundance of fish. This spawner range was calculated by dividing a number of striped bass recruits by a number of spawners (Sharov et al. 2013), converting metric tons of spawner to number of spawners using an average spawner weight of $2000 \mathrm{~g}$, which is in the range of published spawner weights (Morse 1981, Kimmerer et al. 2005, Robillard et al. 2008). Martino and Houde (2012) estimated striped bass age-zero mortality to be 0.068 , which we lowered to 0.041 to reproduce the approximate observed number of age-1 fish. Other age-specific mortalities were calculated by converting striped bass instantaneous mortality (Atlantic States Marine Fisheries Commission 2015) to annual mortality using Equation A1.1 (Gulland 1969) and then to weekly mortality using Equation A1.2 (Krebs 2014). The initial weekly mortality rates for ages 1 , 2, 3, 4, 5, and 6+ were 0.022, 0.013, 0.009, 0.005, 0.004, and 0.003, respectively (Atlantic States Marine Fisheries Commission 2015). These were lowered to maintain a stable population over the long term. Other adjustments including raising the lifespan from 18.6 (the average lifespan of striped bass, bluefish, and summer flounder; Froese and Pauly 2019) to 21 years, raising the L.inf of 40 inches (the average of the three species; Froese and Pauly 2019) to 50 inches, and increasing the $\mathrm{K}$ of 0.18 (the average of the three species; Froese and Pauly 2019) to 0.2 .

Although we initiated the model based on an unweighted average, the adjusted values fall within the range for these three species (striped bass, bluefish, summer flounder) and it is, in fact, the case that the populations of these species in Narragansett Bay are not equal, so changing the initial unweighted estimate is not unreasonable. We focused the tuning first on the age-specific mortality data because they came from striped bass alone, and data were not available for bluefish and summer flounder. So as 
to not lower the mortalities to unrealistic levels, we made slight adjustments in the other parameters to achieve population stability. With these adjusted values, the model was run for 200 years with no fishing and determined to be stable, represented as no increasing or decreasing trend in the population or size distribution.

\section{Model coupling}

Here we describe the two-way linkage of the food web and fisher behavior models, which together we have termed the "socialecological model" (Fig. 1). Our work began with the EwE food web model described by Innes-Gold et al (2020), which ran from 1994 to 2018. In separate trials, each of the four commercial harvest $F$ values were added to the existing time series used as a forcing function in the food web model (1994-2018) in the year 2019. All other forcing functions were held constant at their 2018 values. The food web model was then run for one additional year, outputting predicted piscivorous fish biomass in 2020. The total piscivorous fish biomass (in $\mathrm{g} / \mathrm{m}^{2}$ ) was then converted to number of fish to start the fisher behavior model (Table 1), based on a striped bass length distribution (Table A1.1). Table 1 shows how each commercial harvest scenario led to a different piscivorous fish biomass and thus a different starting number of piscivorous fish for the fisher behavior model. The fisher behavior model was run for one season ( 26 weeks), and the number of removals (kept fish + dead discards) was converted to a piscivorous fish fishing mortality rate $(\mathrm{F})$. The number of removed fish was converted into a caught biomass $\left(\mathrm{g} / \mathrm{m}^{2}\right)$ using the reverse of the methods described to convert the $\mathrm{g} / \mathrm{m}^{2}$ biomass into a count of fish. The caught biomass $\left(\mathrm{g} / \mathrm{m}^{2}\right)$ was then divided by the biomass that had been used as the input to the fisher behavior model for that timestep to calculate an $\mathrm{F}$ value. Because the original piscivorous fish $\mathrm{F}$ value used in the food web model was the summation of commercial and recreational $\mathrm{F}$, the new $\mathrm{F}$ value calculated from the fisher behavior model was added to a commercial $\mathrm{F}$ value, assumed to be constant from 2018 for the projections $(\sim 0.03)$. This combined $\mathrm{F}$ value was then put back into the forcing function time series as the piscivorous fish F in 2020 (and all other forcing functions remained constant). The food web model was then run again for an additional year, through 2021, where the resulting piscivorous fish biomass was used as the input to the fisher behavior model and the process was repeated. This iterative process was applied each year through 2030.

\section{Trial types}

\section{Commercial harvest trials}

The commercial harvest trials were done solely in the food web model. We simulated four scenarios to explore how different amounts of commercial forage fish harvest affect piscivorous fish and other functional groups. Forage fish fishing mortality is a forcing function time series used in the food web model and is applied to the forage fish functional group. We tested the following range of forage fish fishing mortality scenarios: a closed fishery with zero harvest $(\mathrm{F}=0)$, status quo (an average from the 2014-2018 F values in the food web model time series, $F=0.202$ ), an intermediate scenario (the average of the status quo and extreme scenarios, $F=1.68$ ), and an extreme scenario (the highest $F$ value in the food web model time series, which was from the year 2000, F = 3.167). In separate trials, each $F$ value was entered starting in the year 2019 and held constant for the next 10 years (example: $F=0$ for 2019-2029). In each of the food web model forecasts, the other forcing functions ( $F$ for other functional groups, phytoplankton biomass, cultured shellfish biomass) were held constant at their 2018 value for the next 10 years. The response variables studied in this test were the biomasses of the mid and upper trophic level functional groups.

\section{Abundance-catch relationship trials}

The abundance-catch relationship trials were conducted in the coupled social-ecological model. One source of uncertainty in this model is the relationship between fish abundance and the probability of a fisher successfully catching a fish because this relationship has not been defined for Narragansett Bay. The three types of functions described above were used in separate fisher behavior model trials to predict whether or not a given fishing trip will be successful in catching a sublegal or keeper size fish based on the number of sublegal or keeper size fish available (Fig. 3 ). All of these trials used a satisfaction loss rate of 0.5. Each of the trials (power, linear, static) was conducted in each of the four commercial forage fish harvest scenarios (12 trials total) and compared only to the other trials in the same scenario. Each specific trial was run in the coupled social-ecological model for 10 years (until 2030). Testing these different abundance-catch relationships allowed for assessing how sensitive the response variables of piscivorous fish biomass, the number of fish caught, and fisher end of season satisfaction were to the assumed relationship.

\section{Satisfaction loss rate trials}

The satisfaction loss rate trials were also conducted in the coupled social-ecological model. The satisfaction loss rate of recreational fishers is also a source of uncertainty in the model. Such uncertainty can be consequential given that satisfaction rate directly determines future participation and effort in the fishery. We conducted three trials where fishers lose one, half, or zero satisfaction points after an unsuccessful trip, i.e., zero fish are caught. During these trials, the abundance-catch relationship was always defined using the power function because that was the null model. Each of the three trials (one, half, zero) was conducted in each of the four commercial forage fish harvest scenarios (12 trials total) and only compared to other trials in the same scenario. Each trial was run in the coupled social-ecological model for 10 years (until 2030). In this test, the three response variables were also piscivorous fish biomass, number of fish caught, and fisher end of season satisfaction.

\section{Analysis}

In the commercial harvest scenario trials, we report differences in the organism biomass forecasted by the food web model at the year 2030. In the abundance-catch relationship trials, we detail differences between the linear, static, and power trials for three response variables: piscivorous fish biomass, the number of fish caught and kept, i.e., "keepers," and end of season satisfaction. For the satisfaction loss trials, differences between the one, half, and zero trials using the same three response variables are described. No statistical tests were conducted so as to avoid drawing inappropriate conclusions from simulation modeling (White et al. 2014). 


\section{RESULTS}

\section{Commercial harvest scenario trials}

In the stand-alone food web model forecasts, the highest biomasses of all fish groups occurred when forage fish harvest was prohibited (Fig. 4). In the year 2030, the extreme, intermediate, and status quo harvest scenarios yielded forage fish biomasses that were $44.9 \%, 64.1 \%$, and $94.7 \%$ of the biomass under zero harvest, respectively (Table A1.3). Piscivorous fish indicated a similar pattern to their prey (forage fish), albeit of smaller magnitude (Fig. 4). The extreme, intermediate, and status quo harvest scenarios yielded piscivorous fish biomasses that were $75.4 \%, 81.7 \%$, and $96.8 \%$ of the predicted biomass under zero harvest, respectively (Table A1.3). The other mid- and uppertrophic level groups showed a range of responses to these various forage fish harvest scenarios; carnivorous benthos biomass was largely unaffected, while benthivorous fish biomass decreased slightly with increasing forage fish harvest. Both large and small squid also responded in the same pattern, with increasing forage fish harvest leading to lower projected squid biomass (Fig. 4). The sharpest initial declines in biomass were seen in forage fish and both groups of squid in the intermediate and extreme harvest scenarios (Fig. 4). For all groups, the forecasted biomasses were similar for the zero and status quo harvest scenarios because the status quo fishing mortality was very low.

Fig. 4. The Ecopath with Ecosim food web model biomass trajectories under four different scenarios of commercial forage fish harvest. Note that scenario forecasts for carnivorous benthos were similar, with forecasts overlaying each other.
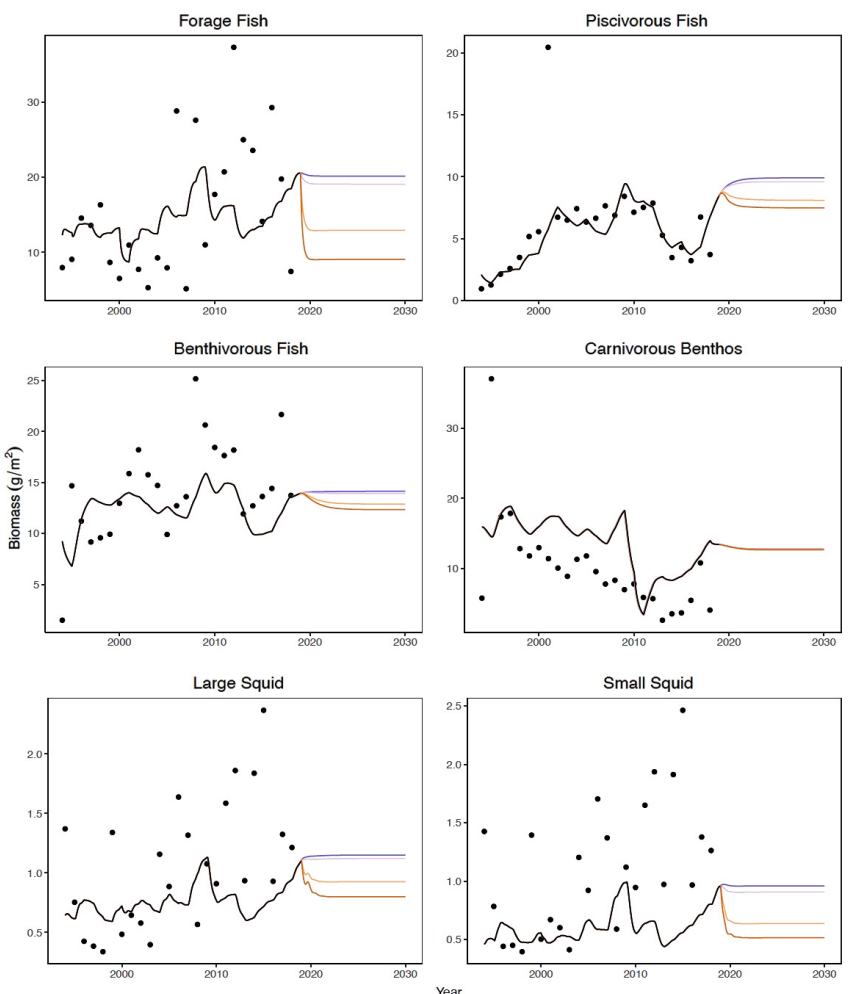

Forage Fish - Zero - Status Quo - Intermediate - Extreme

\section{Abundance-catch relationship trials}

Varying the nature of the abundance-catch relationship in the fisher behavior model led to differences in all three response variables (Fig. 5a). Our model trials using a power function to define the abundance-catch relationship predicted a higher number of fish caught, higher fisher satisfaction, and lower fish biomass (Fig. 5a, A1.1). Trials with a linear or static relationship predicted fewer fish caught, lower fisher satisfaction, and a higher subsequent biomass (Fig. 5a). In some scenarios, i.e. zero commercial harvest, the linear and static trials did not produce large differences in response variables, while in other scenarios, i.e., intermediate commercial harvest, they did (Fig. 5a). The power function trials generally produced fish biomass and a number of fish caught that had larger differences from the static or linear trial results, which were often similar. For end of season satisfaction, this distinction was less present (Fig. 5a). The different commercial forage fish harvest scenarios led to large differences in piscivorous fish biomass, with higher harvest leading to lower forecasted biomass, although the zero and status quo harvest scenarios produced similar biomass projections (Fig. 6a). Notably, the harvest scenarios caused few notable differences in number of keepers caught and in fisher end of season satisfaction (Fig. 6a).

\section{Satisfaction loss rate trials}

The satisfaction loss rate produced distinctly different outcomes in the number of fish caught and fisher end of season satisfaction but had fewer distinguishable patterns on piscivorous fish biomass (Fig. 5b). The satisfaction loss rate of zero led to a higher number of fish caught, higher fisher satisfaction, and lower projected fish biomass, while the satisfaction loss rate of one led to a lower number of fish caught, lower fisher satisfaction, and higher projected piscivorous fish biomass (Fig. 5b, A1.2). As before, the higher commercial forage fish harvest led to lower piscivorous fish biomass (Fig. 6b). The harvest scenarios caused few pronounced differences in number of keepers caught and fisher end of season satisfaction (Fig. 6b).

\section{DISCUSSION}

By linking a food web model with a fisher behavior model, we have demonstrated a social-ecological method that could be useful for testing social responses to environmental and anthropogenic perturbations. We have shown that including a human dimensions component can lead to large differences in model-predicted values of ecological variables, i.e. fish biomass. This can be seen when our coupled model forecasts are compared to the stand-alone food web model forecasts, which did not include the fisher behavior model. By coupling these two models together, the predicted biomass values differed from those predicted by the food web model alone, regardless of which trial type was run. This lends strong support to previous calls for inclusion of human behavior in ecosystem modeling and ecosystem-based fisheries management (Hall-Arber et al. 2009, Hornborg et al. 2019). Previous EwE models have employed a value chain extension (Christensen et al. 2011) or simulated fisheries management strategies within EwE (Martell et al. 2002, Chagaris et al. 2015), but to our knowledge, EwE has not been linked to an ABM or a dynamic fisher behavior model. Creating a two-way coupling between an EwE model and a temporally dynamic model of fisher behavior, i.e., an ABM, has allowed for a more complete understanding of the social-ecological system and for users to elucidate important mechanisms that can 
Fig. 5. The mean and data spread (of each 8-year trial) of piscivorous fish biomass, the number of keepers caught, and fisher end of season satisfaction for the four harvest scenarios. Color indicates the type of fisher behavior model trial, where the top row (A) shows the abundance-catch relationship trials, and the bottom row (B) shows the satisfaction loss rate trials.

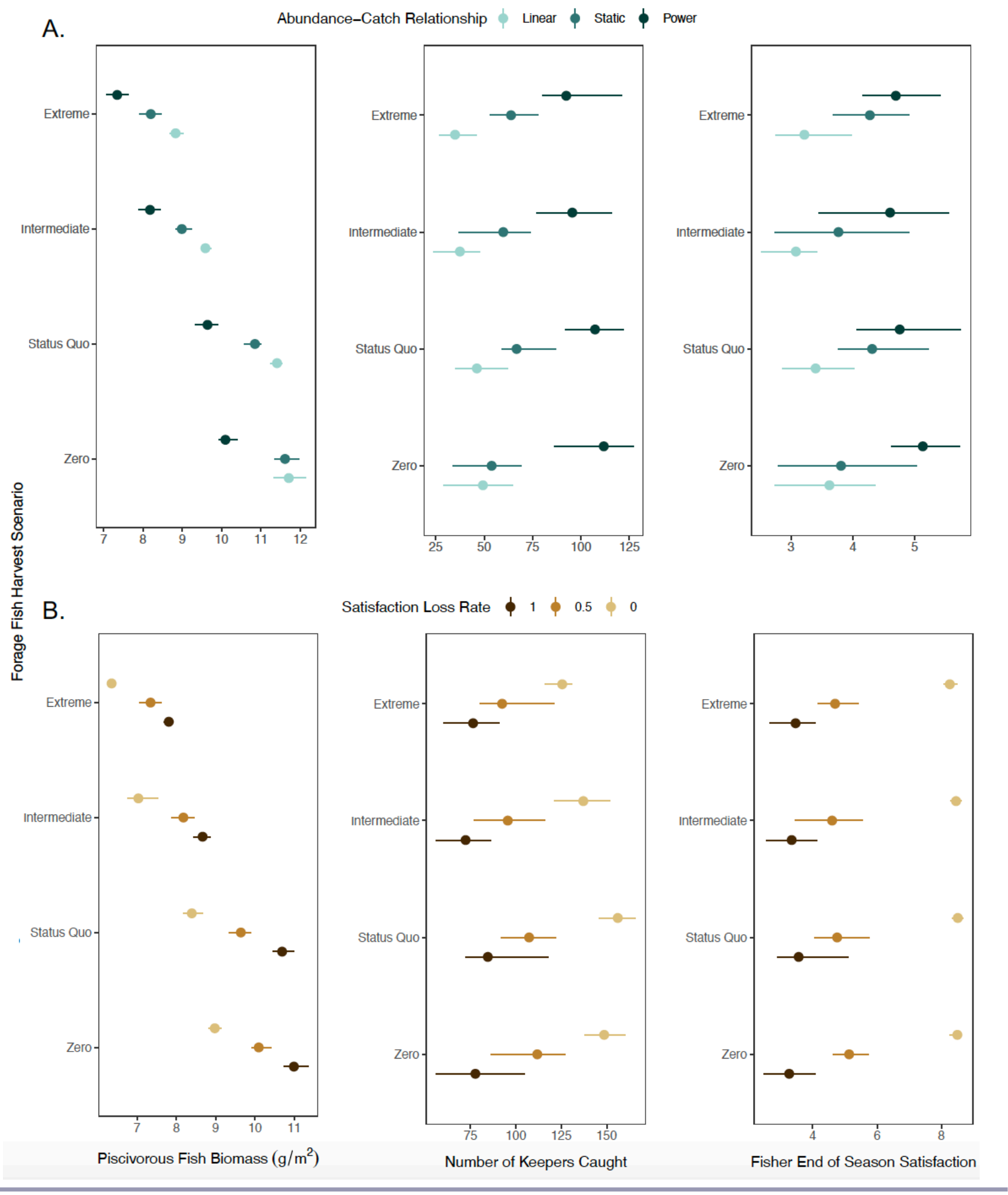


Fig. 6. The mean and data spread (of each 8-year trial) of piscivorous fish biomass, the number of keepers caught, and recreational fisher end of season satisfaction across harvest scenarios, where the top row (A) shows the abundance-catch relationship trials, and the bottom row (B) shows the satisfaction loss rate trials. Color indicates the scenario of commercial forage fish harvest.
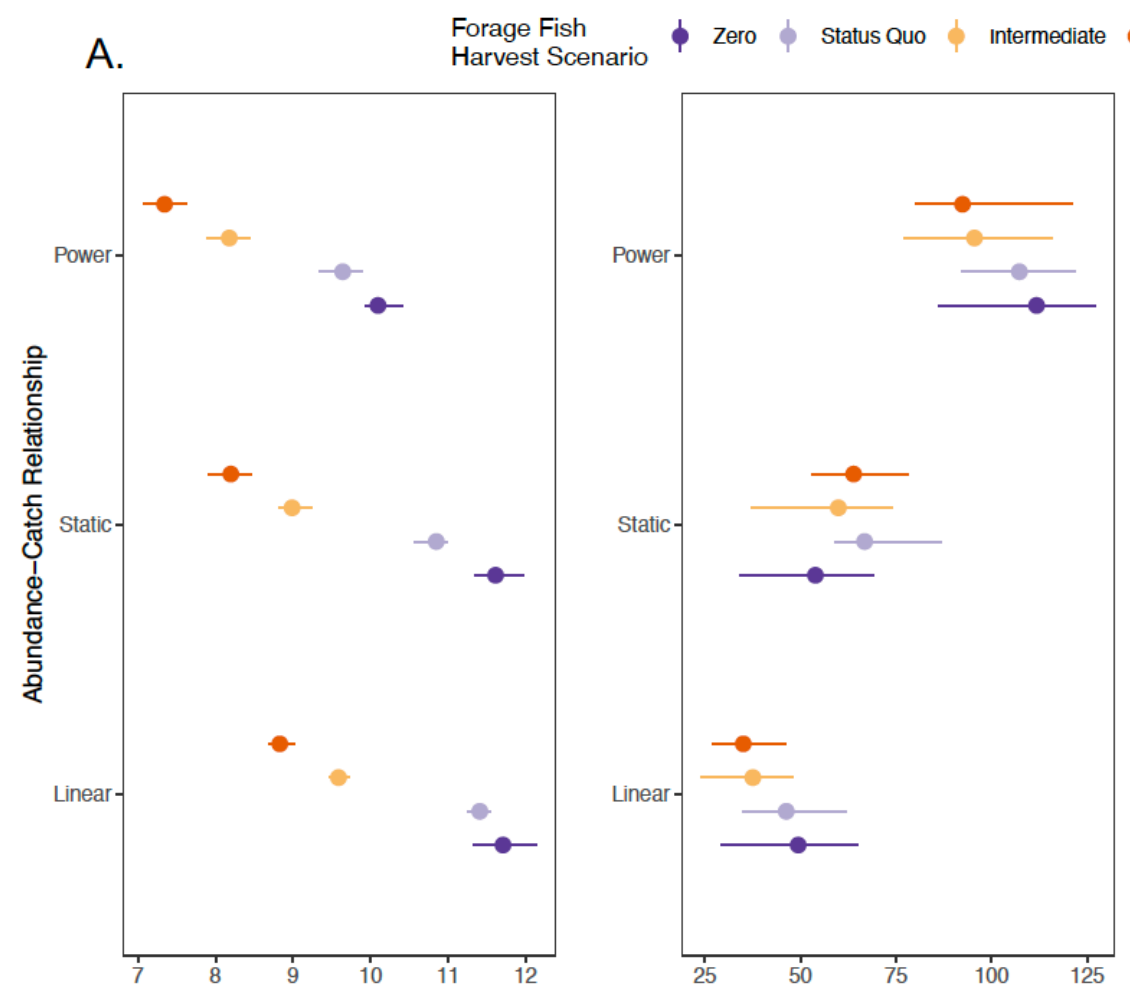

Extreme

B.
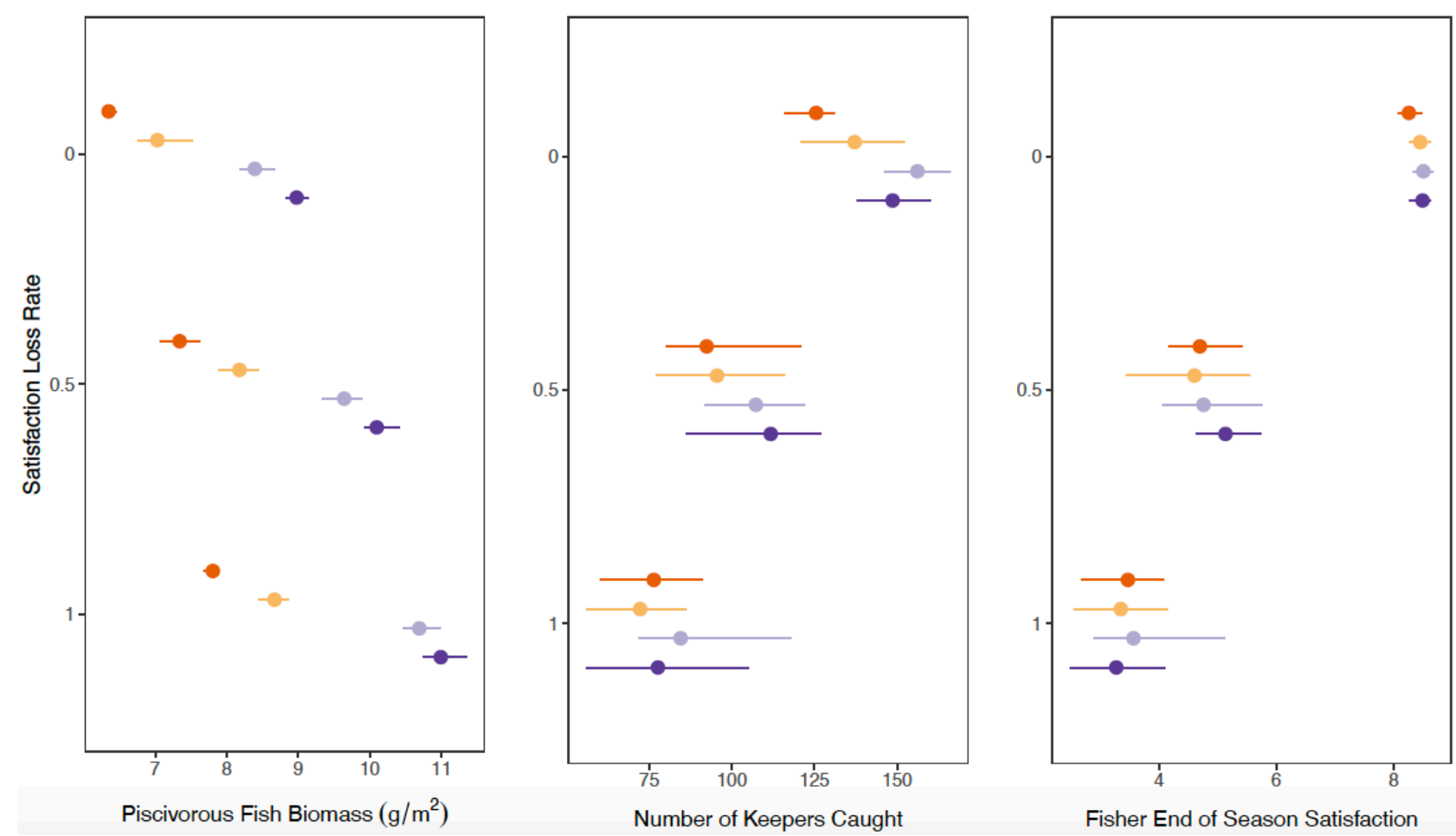

Fisher End of Season Satisfaction 
lead to different responses of the system. Such a framework presents the possibility of exploring social-ecological scenarios using models, including not only investigating human impacts on the ecosystem but also how resource users respond to changes in the ecosystem. Because managers regulate the actions of humans, research and modeling efforts aiming to inform management must consider the social domain as part of the ecosystem.

\section{Commercial harvest scenario}

The food web model indicated that the current (status quo) low level of fishing pressure on forage fish is not having a dramatic impact on forage or piscivorous fish biomass in Narragansett Bay. If there is higher fishing pressure, i.e., the extreme scenario, the model projected that there would be a decrease in all three groups of fish and squid, but that this had fairly minimal impacts on the number of fish caught by the recreational fishery. It is very unlikely that future commercial fishing pressure on planktivorous fish would reach the extreme level tested given the current catch limits in place. Both size classes of squid showed fairly large decreases between the different forage fish harvest scenarios because forage fish made up a sizable proportion ( $27 \%$ for small squid, $50 \%$ for large squid) of squid diet in this Narragansett Bay model (InnesGold et al. 2020). It is worth noting that this food web model had less precise fits for both groups of squid compared to the three fish groups, which may lead to less reliable projections (InnesGold et al. 2020). In the food web model, predators switched prey if their preferred prey source was diminished, which buffered some of the food web impacts from the harvest of forage fish. Allowing prey switching is ecologically justified because estuarine predators have repeatedly been shown to switch their diet based on varying prey availability in changing environments (Pihl et al. 1992, Nobriga and Feyrer 2008, Szczepanski 2013; M. Heinichen unpublished manuscript). Overall, the forage fish harvest scenario did not appear to be a main driver in the number of piscivorous fish caught recreationally or recreational fisher satisfaction.

Although these results suggest that current forage fishing pressure within Narragansett Bay is not having large social or ecological impacts, this may not be generalizable to forage fish harvest elsewhere. Forage fish harvest has been found to have impact predator biomass on larger scales, depending on the species of interest (Buchheister et al. 2017). There are several reasons why our scale of impact on predator biomass might have been smaller. By grouping multiple species together in our forage and piscivorous fish functional groups, we were unable to determine which species had the strongest responses. Buchheister et al. (2017) found that striped bass responded strongly to changes in menhaden harvest, while other predators did not respond as strongly. Because this EwE model was designed for broad, ecosystem-level questions and grouped striped bass in with other piscivorous fish, i.e. bluefish and summer flounder, it cannot be used to isolate changes in specific species. Additionally, Narragansett Bay is not the most heavily commercially fished estuary along the U.S. East Coast. The Chesapeake Bay, for example, has much higher harvest levels of forage fish and a strict management system in place meant to account for the ecosystem services of menhaden (SEDAR 2015).

It is also important to note that in the forecasts we performed, other forcing functions (phytoplankton biomass, cultured shellfish biomass, fishing mortality for other fished groups) were held constant at their 2018 levels. This was done to isolate the effects of forage fish harvest and explore specifically how forage fish fishing pressure impacts the ecosystem. Given the importance of phytoplankton as a driver in the EwE model (Innes-Gold et al. 2020) and history of nutrient inputs into Narragansett Bay (Nixon et al.2008), future simulations could explore the combined effects of varying fishing pressure and phytoplankton (as a proxy for nutrient inputs). For example, reduced primary production could lead to decreased forage fish because of the strong link between plankton and forage fish (Cury et al. 2000). Given that the relationship between nutrient reductions and primary producers is non-linear (Oviatt et al. 2017), this is an area warranting future work.

\section{Abundance-catch relationship}

Varying the abundance-catch relationship in the coupled model simulations led to changes in the number of fish caught and subsequent fish biomass and fisher satisfaction. We chose to test the abundance-catch relationship because higher abundance of fish has led to higher catch in other recreational fisheries (Pitman et al. 2019), however there is no consensus on the best method to approximate this relationship. For certain species, abundance and catch per unit effort (CPUE) can have a proportional relationship, but for other single or grouped species, CPUE has been found to be a poor abundance index (Richards and Schnute 1986, Haggarty and King 2006). Historically, the linear method to relate abundance and catch was commonly used for stock assessments (Cooke and Beddington 1984). Although the linear method has since been questioned as an oversimplification of this relationship (Peterman and Steer 1981, Bannerot and Austin 1983), it has also been found to perform better than a power curve in some cases (Tsuboi and Endou 2008). The power function is another common method and has been suggested as a more appropriate alternative to a linear function (Hilborn 1985, Harley et al. 2001, Gaertner and Dreyfus-Leon 2004). We chose to include an additional, static relationship, because there may be no relationship between abundance and catch (Tsuboi and Endou 2008). The lack of consensus on a defined abundance-catch relationship may be due to differences in species vulnerabilities to fishing gear (Tsuboi and Endou 2008). Other factors can also influence CPUE, such as fish maturity, fish density, area swept, year, season, fishing gear, and fisher behavior (Richards and Schnute 1986, Large 1992).

Our work shows the importance of testing multiple abundancecatch relationships when there is uncertainty. In our model, the three different abundance-catch relationships led to very different model outcomes because of their underlying functional form. When using the power function, the predicted number of fish caught at times was double the number predicted in the linear or static trials. This difference led to discrepancies in fishers' end of season satisfaction, which then affected their likelihood to continue fishing. In comparison, the commercial harvest scenario of forage fish had fewer impacts on the number of piscivorous fish caught or recreational fisher satisfaction. These results showed that the abundance-catch relationship needs to be clearly defined to have confidence in model projections. We have, therefore, highlighted another area for future research: quantifying the abundance-catch relationship for recreational fishers in Narragansett Bay. The nature of this relationship varies depending on the location and species (Gaertner and Dreyfus- 
Leon 2004, Tsuboi and Endou 2008), making it difficult to transfer the relationship derived from one fishery to another. The factors that play into this relationship are both social, i.e., fishing gear and behavior, and ecological, i.e. fish abundance, density, and population dynamics. It is particularly challenging to account for behavioral changes that affect catch rates, affirming the need for future research to focus on decreasing uncertainty outside of a purely ecological setting (Fulton et al. 2011).

\section{Satisfaction loss rate}

In the coupled model simulations, the satisfaction loss rate led to large differences in the measured response variables. Our satisfaction variable is a proxy for the many factors that go into a fisher's decision-making process on if they will fish at a given time, with satisfaction increasing upon catching a fish (Pitman et al. 2019). In our model, when fishers became discouraged quickly and went fishing less frequently, it led to projections of fewer fish being caught and higher fish biomass. On the other hand, when the failure of a previous trip did not cause fishers to become discouraged, projections of the number of fish caught doubled. Similar to the abundance-catch relationship, the satisfaction loss rate led to changes in all response variables, while commercial harvest scenario mainly affected fish biomass. Because of this impact, quantifying the rate at which fishers exit the fishery is also important in order to have reliable model projections.

Key data gaps to fill include discovering the extent to which a previous trip influences a fisher's decision to fish and if a successful trip increases satisfaction more than an unsuccessful trip decreases it, which has been suggested by an ABM of a coral reef recreational fishery (Shafer 2007). Ideally, these data would be collected from surveys of the recreational fishing community in Narragansett Bay because this could differ between locations due to diverse behavior among recreational fishers (Mackay et al. 2020). Some useful survey questions comprise how likely they would be to keep or release a keeper, as well as how much their interest in fishing would change depending on their previous fishing success. This could also be done by monitoring fishers and inferring their behavior from collected data (Friedlander et al. 2014). In other locations, there has been high heterogeneity in fishers' willingness to leave the fishery, with many continuing to fish even when they were unsuccessful (Cinner et al. 2009, Muallil et al. 2011). Skill level could also impact fisher satisfaction. Although data limitations did not allow us to include a fisher skill level attribute, future research could parameterize this variable by collecting data on the number of years each fisher had been angling along with their fishing success. In other locations, less skilled fishers seem to be more inclined to leave the fishery as stocks decline (van Poorten et al. 2016). Although success on previous trips, as well as skill level, may be an important part of a fisher's decision to fish, the model could also benefit from the incorporation of other factors, such as fisher economic status, weather, and fuel price (Cinner et al. 2009, Cooper and Jarre 2017, Daw et al. 2017). Even though Narragansett Bay has a plethora of long-term environmental datasets, there is a definitive lack of social data describing fishery attributes that is needed to give nuance into fisher decision making. Understanding the behavior of recreational fishers is essential to promote the sustainability and resilience of recreational fisheries (Arlinghaus and Cooke 2009, Arlinghaus et al. 2013)

\section{Management implications}

The results from our coupled model demonstrate that the inclusion of the human dimension, and more specifically how the social system is represented, i.e., how parameters such as satisfaction loss are defined, can change model outcomes. These findings add to the growing amount of literature pinpointing the need for human behavior to be incorporated into environmental, and specifically fisheries, management using ecosystem-based approaches (i.e., Fulton et al. 2011, Asah et al. 2014, Hornborg et al. 2019). The relatively few papers that take steps in incorporating fisher behavior into management often focus on economic indicators (Hornborg et al. 2019). Whereas economic incentives drive commercial fisheries, this may not be the case for recreational fisheries. For example, studies of fisher behavior have shown that in addition to economic gain, factors like the desire to conform to social norms, uphold identity, and experience esteem are also important drivers (Hall-Arber et al. 2009). In fact, it is common for fishers to be willing to pay for the opportunity to fish (Cantrell et al. 2004, Johnston et al. 2006). For many fishers who continue to fish despite economic loss, fishing can be a form of recreation and a way to preserve self-image (Wijermans et al. 2020). Satisfaction was chosen as our model variable because it is flexible enough to capture these non-economic behavioral motivators. In this study, we have shown that incorporating recreational fishing dynamics can lead to different forecasts of fish biomass and the number of fish caught, thus affecting the food web. The model coupling framework we have demonstrated could be particularly useful for management strategy evaluations, where there is the need to assess and balance conflicting objectives of different stakeholders (Smith et al. 1999). Going forward, it is imperative for scientists and managers to work with stakeholders to define the required metrics for assessing performance prior to conducting this research.

We did not incorporate spatial dynamics into the food web or fisher behavior models because of a lack of fish and fisher distribution data in Narragansett Bay. The spatial distribution of forage fish may be particularly important to include because their distribution has the potential to impact their piscivorous predators more than their abundance does (Hilborn et al. 2017). Were these data available, adding a spatial component would allow for increased realism and the exploration of additional social-ecological questions, such as how fishing success varies over time at different locations throughout the Bay. Spatial distribution would also allow for the inclusion of additional behavioral elements, such as competition and collaboration between fishers, which have shown to be important particularly in small-scale fisheries (Pollnac and Poggie 1991, Basurto et al. 2016). The population age structure used in our model was estimated from striped bass data. Incorporating similar data for bluefish and summer flounder, when available, would help resolve the effect the population age structure has on the model outputs. Fish population age structure is an area of research that could be further explored using the multi-stanza tool of the EwE model, which breaks functional groups up into size classes. In addition, we held commercial fishing pressure static but in the range of historical data. In order to create a model with the intention of forecasting ecosystem change, the fisher behavior model should be expanded to include commercial fleet dynamics and their response to real-time fishery profitability. Given these limitations, 
drawing concrete conclusions from our fisher behavior model on how the Narragansett Bay recreational fishery will change over time should not be inferred from this work. We aimed to create a reproducible yet flexible methodology for incorporating human behavior in a coupled social-ecological model built using established modeling platforms. We have also demonstrated that including these dynamics yields much different projections of important metrics such as fish biomass, catch, and fisher satisfaction. This model focuses on realism and generality as a goal, and accuracy can be further improved by filling the data gaps mentioned previously (Levins 1966).

Consideration of the entire ecosystem has become a high priority in fisheries management as rapid environmental and human change becomes the new normal; ecosystem-based fisheries management has been an ultimate goal for fisheries management agencies globally, with limited implementation success to date. Perhaps one of the most significant applications to-date, the Atlantic States Marine Fisheries Commission adopted the use of Ecological References Points for the management of Atlantic menhaden along the U.S. Atlantic coast, moving away from a single-species approach and now having quota specification informed by managing menhaden harvest in the context of itself and predators, i.e., striped bass (SEDAR 2020). However, for full ecosystem-based fisheries management implementation, these ecosystem approaches must formally include the human dimensions via simulation models. The inclusion of fisher behavior is especially important when asking questions about fisheries trade-offs, such as the trade-offs associated with ecological reference points for menhaden (Chagaris et al. 2020). Recreational fishers have expressed concern that menhaden fishing is depleting the prey source for the predators they prefer to target (Chase 2019). In a system such as this one, the changing behavior of fishers could have profound impacts on the ecosystem as well as other fishing sectors. We have shown that incorporating fisher behavior into models can change fish biomass projections and thus should be a priority for future ecosystem-based fisheries management efforts. Furthermore, we have provided a methodology for the creation of such a coupled model. Perhaps the main barrier to the successful inclusion of human behavior in models, at this point, is the lack of data on these human dimensions. In order to understand how ecosystems will change over time, researchers need to collect and incorporate data on the behavior of resource users. Although the absence of data on spatial distribution of fish and fishers, as well as region-specific fisher behavior, limits the predictive use of our social-ecological model, it is a useful tool for three main reasons. First, it has allowed us to explore general patterns of the linkage between the commercial and recreational fisheries of Narragansett Bay. Knowing the extent to which these two fishing sectors are linked is important when deciding if and how they should be considered in the management of one another. Second, our social-ecological model provides a base model to which new data can be added to expand the accuracy of the model's representation of the Narragansett Bay recreational fishery. Finally, there are no examples of coupled EwE and agent-based models that we are aware of, making this method novel and providing a framework of how to incorporate human behavior for other fisheries to follow.
Responses to this article can be read online at: https://www.ecologyandsociety.org/issues/responses. php/12451

\section{Acknowledgments:}

This work was supported by Rhode Island National Science Foundation Established Program to Stimulate Competitive Research Grant \#OIA-165522. We thank Kelvin Gorospe, Tracey Dalton, Emi Uchida, and Todd Guilfoos for their input during the conceptualizing and building of the model. We also thank the National Socio-Environmental Synthesis Center (SESYNC) for hosting an agent-based modeling workshop, and the two anonymous reviewers for their helpful feedback. This research is a contribution of the Rhode Island Marine Fisheries Institute. The views expressed herein are those of the authors and do not necessarily reflect the views of their agencies.

\section{Data Availability:}

The models used in this study are available on EcoBase (http:I/ ecobase.ecopath.org/php/protect/base model.php?lang =\&provenance= web\&ident $=\&$ pass $=\&$ action $=$ base \& model $=753$ ) and CoMSES/ OpenABM (the agent-based model).

\section{LITERATURE CITED}

Arlinghaus, R. 2006. On the apparently striking disconnect between motivation and satisfaction in recreational fishing: the case of catch orientation of German anglers. North American Journal of Fisheries Management 26(3):592-605. https://doi. org/10.1577/M04-220.1

Arlinghaus, R., and S. J. Cooke. 2009. Recreational fisheries: socioeconomic importance, conservation issues and management challenges. Pages 39-58 in B. Dickson, J. Hutton, and W. M. Adams, editors. Recreational hunting, conservation and rural livelihoods: science and practice. Blackwell Publishing, Chichester, UK. https://doi.org/10.1002/9781444303179.ch3

Arlinghaus, R., S. J. Cooke, and W. Potts. 2013. Towards resilient recreational fisheries on a global scale through improved understanding of fish and fisher behaviour. Fisheries Management and Ecology 20(2-3):91-98. https://doi.org/10.1111/ fme. 12027

Asah, S. T., A. D. Guerry, D. J. Blahna, and J. J. Lawler. 2014. Perception, acquisition and use of ecosystem services: human behavior, and ecosystem management and policy implications. Ecosystem Services 10:180-186. https://doi.org/10.1016/j. ecoser.2014.08.003

Atlantic States Marine Fisheries Commission. 2015. 2015 Atlantic striped bass stock assessment update. Atlantic States Marine Fisheries Commission, Arlington, Virginia, USA.

Bannerot, S. P., and C. B. Austin. 1983. Using frequency distributions of catch per unit effort to measure fish-stock abundance. Transactions of the American Fisheries Society 112 
(5):608-617. https://doi.org/10.1577/1548-8659(1983)112<608: UFDOCP $>2.0 . \mathrm{CO} ; 2$

Basurto, X., E. Blanco, M. Nenadovic, and B. Vollan. 2016. Integrating simultaneous prosocial and antisocial behavior into theories of collective action. Science Advances 2(3):e1501220. https://doi.org/10.1126/sciadv.1501220

Boyd, J., and S. Banzhaf. 2007. What are ecosystem services? The need for standardized environmental accounting units. Ecological Economics 63(2-3):616-626. https://doi.org/10.1016/j.ecolecon.2007.01.002

Buchheister, A., T. J. Miller, and E. D. Houde. 2017. Evaluating ecosystem-based reference points for Atlantic menhaden. Marine and Coastal Fisheries 9(1):457-478. https://doi.org/10.1080/19425120.2017 .1360420

Burgess, M. G., E. Carrella, M. Drexler, R. L. Axtell, R. M. Bailey, J. R. Watson, R. B. Cabral, M. Clemence, C. Costello, C. Dorsett, S. D. Gaines, E. S. Klein, P. Koralus, G. Leonard, S. A. Levin, L. R. Little, J. Lynham, J. K. Madsen, A. Merkl, B. Owashi, S. E. Saul, I. E. van Putten, and S. Wilcox. 2020. Opportunities for agent-based modelling in human dimensions of fisheries. Fish and Fisheries 21(3):570-587. https://doi.org/10.1111/faf.12447

Campbell, R. A. 2004. CPUE standardisation and the construction of indices of stock abundance in a spatially varying fishery using general linear models. Fisheries Research 70 (2-3):209-227. https://doi.org/10.1016/j.fishres.2004.08.026

Cantrell, R. N., M. Garcia, P. Leung, and D. Ziemann. 2004. Recreational anglers' willingness to pay for increased catch rates of Pacific threadfin (Polydactylus sexfilis) in Hawaii. Fisheries Research 68(1-3):149-158. https://doi.org/10.1016/j.fishres.2004.01.003

Cenek, M., and M. Franklin. 2017. An adaptable agent-based model for guiding multi-species Pacific salmon fisheries management within a SES framework. Ecological Modelling 360:132-149. https://doi.org/10.1016/j.ecolmodel.2017.06.024

Chagaris, D., K. Drew, A. Schueller, M. Cieri, J. Brito, and A. Buchheister. 2020. Ecological reference points for Atlantic menhaden established using an ecosystem model of intermediate complexity. Frontiers in Marine Science 7:606417. https://doi. org/10.3389/fmars.2020.606417

Chagaris, D. D., B. Mahmoudi, C. J. Walters, and M. S. Allen. 2015. Simulating the trophic impacts of fishery policy options on the west Florida shelf using Ecopath with Ecosim. Marine and Coastal Fisheries 7(1):44-58. https://doi.org/10.1080/19425120.2014.966216

Chase, C. 2019. Recreational fishing groups formally object to menhaden's MSC nod. SeafoodSource News, 29 March. [online] URL: https://www.seafoodsource.com/news/environment-sustainability/ recreational-fishing-groups-formally-object-to-menhaden-s-msc$\underline{\text { nod }}$

Christensen, V., and D. Pauly. 1992. ECOPATH II - a software for balancing steady-state ecosystem models and calculating network characteristics. Ecological Modelling 61(3-4):169-185. https://doi.org/10.1016/0304-3800(92)90016-8

Christensen, V., J. Steenbeek, and P. Failler. 2011. A combined ecosystem and value chain modeling approach for evaluating societal cost and benefit of fishing. Ecological Modelling 222 (3):857-864. https://doi.org/10.1016/j.ecolmodel.2010.09.030

Christensen, V., C. Walters, and D. Pauly. 2005. Ecopath with Ecosim: a user's guide. Fisheries Centre, University of British Columbia, Vancouver, Canada and ICLARM, Penang, Malaysia.

Cinner, J. E., T. Daw, and T. R. McClanahan. 2009. Socioeconomic factors that affect artisanal fishers' readiness to exit a declining fishery. Conservation Biology 23(1):124-130. https://doi.org/10.1111/j.1523-1739.2008.01041.x

Coll, M., A. Bundy, and L. J. Shannon. 2009. Ecosystem modelling using the Ecopath with Ecosim approach. Pages 225-291 in B. A. Megrey and E. Moksness, editors. Computers in fisheries research. Springer, Dordrecht, The Netherlands. https:// doi.org/10.1007/978-1-4020-8636-6 8

Collie, J. S., A. D. Wood, and H. P. Jeffries. 2008. Long-term shifts in the species composition of a coastal fish community. Canadian Journal of Fisheries and Aquatic Sciences 65:1352-1365. https:// doi.org/10.1139/F08-048

Cooke, J. G., and J. R. Beddington. 1984. The relationship between catch rates and abundance in fisheries. Mathematical Medicine and Biology 1(4):391-405. https://doi.org/10.1093/ imammb/1.4.391

Cooper, R., and A. Jarre. 2017. An agent-based model of the South African offshore hake trawl industry: Part I model description and validation. Ecological Economics 142:268-281. https://doi.org/10.1016/j.ecolecon.2017.06.026

Cury, P., A. Bakun, R. J. M. Crawford, A. Jarre, R. A. Quiñones, L. J. Shannon, and H. M. Verheye 2000. Small pelagics in upwelling systems: patterns of interaction and structural changes in "wasp-waist" ecosystems. ICES Journal of Marine Science 57 (3):603-618. https://doi.org/10.1006/jmsc.2000.0712

Dalton, T., R. Thompson, and D. Jin. 2010. Mapping human dimensions in marine spatial planning and management: an example from Narragansett Bay, Rhode Island. Marine Policy 34 (2):309-319. https://doi.org/10.1016/j.marpol.2009.08.001

Daw, T. M., J. E. Cinner, T. R. McClanahan, K. Brown, S. M. Stead, N. A. J. Graham, and J. Maina. 2017. To fish or not to fish: factors at multiple scales affecting artisanal fishers' readiness to exit a declining fishery. PLOS ONE 12(2):e0172075. https://doi. org/10.1371/journal.pone.0172075

Diodati, P. J., and R. A. Richards. 1996. Mortality of striped bass hooked and released in salt water. Transactions of the American Fisheries Society 125(2):300-307. https://doi.org/10.1577/1548-8659 (1996) $125<0300:$ MOSBHA > 2.3.CO;2

Engelhard, G. H., M. A. Peck, A. Rindorf, S. C. Smout, M. van Deurs, K. Raab, K. H. Andersen, S. Garthe, R. A. M. Lauerburg, F. Scott, T. Brunel, G. Aarts, T. van Kooten, and M. DickeyCollas. 2014. Forage fish, their fisheries, and their predators: who drives whom? ICES Journal of Marine Science 71(1):90-104. https://doi.org/10.1093/icesjms/fst087

Essington, T. E., P. E. Moriarty, H. E. Froehlich, E. E. Hodgson, L. E. Koehn, K. L. Oken, M. C. Siple, and C. C. Stawitz. 2015. Fishing amplifies forage fish population collapses. Proceedings 
of the National Academy of Sciences 112(21):6648-6652. https:// doi.org/10.1073/pnas. 1422020112

Friedlander, A., P. Curry, M. Donovan, A. Filous, J. Giddens, W. Goodell, K. Kamikawa, H. Koike, E. Schemmel, K. Stamoulis, and P. Usseglio. 2014. Assessing lay-gillnet regulations in protected and unprotected areas on windward O'ahu. Fisheries Ecology Research Lab, University of Hawai'i, Honolulu, Hawai'i, USA.

Froese, R., and D. Pauly. 2019. FishBase. https://www.fishbase. org

Fulton, E. A., A. D. M. Smith, D. C. Smith, and I. E. van Putten. 2011. Human behaviour: the key source of uncertainty in fisheries management. Fish and Fisheries 12(1):2-17. https://doi. org/10.1111/j.1467-2979.2010.00371.x

Gaertner, D., and M. Dreyfus-Leon. 2004. Analysis of non-linear relationships between catch per unit effort and abundance in a tuna purse-seine fishery simulated with artificial neural networks. ICES Journal of Marine Science 61(5):812-820. https://doi. org/10.1016/j.icesjms.2004.05.002

Grimm, V., U. Berger, F. Bastiansen, S. Eliassen, V. Ginot, J. Giske, J. Goss-Custard, T. Grand, S. K. Heinz, G. Huse, A. Huth, J. U. Jepsen, C. Jørgensen, W. M. Mooij, B. Müller, G. Pe'er, C. Piou, S. F. Railsback, A. M. Robbins, M. M. Robbins, E. Rossmanith, N. Rüger, E. Strand, S. Souissi, R. A. Stillman, R. Vabø, U. Visser, and D. L. DeAngelis. 2006. A standard protocol for describing individual-based and agent-based models. Ecological Modelling 198(1):115-126. https://doi.org/10.1016/j.ecolmodel.2006.04.023

Grimm, V., U. Berger, D. L. DeAngelis, J. G. Polhill, J. Giske, and S. F. Railsback. 2010. The ODD protocol: a review and first update. Ecological Modelling 221(23):2760-2768. https://doi. org/10.1016/j.ecolmodel.2010.08.019

Grimm, V., S. F. Railsback, C. E. Vincenot, U. Berger, C. Gallagher, D. L. DeAngelis, B. Edmonds, J. Ge, J. Giske, J. Groeneveld, A. S. A. Johnston, A. Milles, J. Nabe-Nielsen, J. G. Polhill, V. Radchuk, M.-S. Rohwäder, R. A. Stillman, J. C. Thiele, and D. Ayllón. 2020. The ODD protocol for describing agentbased and other simulation models: a second update to improve clarity, replication, and structural realism. Journal of Artificial Societies and Social Simulation 23(2):7. https://doi.org/10.18564/ jasss.4259

Guerrero, A. M., N. J. Bennett, K. A. Wilson, N. Carter, D. Gill, M. Mills, C. D. Ives, M. J. Selinske, C. Larrosa, S. Bekessy, F. A. Januchowski-Hartley, H. Travers, C. A. Wyborn, and A. Nuno. 2018. Achieving the promise of integration in social-ecological research: a review and prospectus. Ecology and Society 23(3):38. https://doi.org/10.5751/ES-10232-230338

Gulland, J. A. 1969. Section 5. Mortalities. Page Manual of Methods for Fish Stock Assessment - Part 1. Fish Population Analysis. Food and Agriculture Organization of the United Nations, Rome, Italy.

Haggarty, D. R., and J. R. King. 2006. CPUE as an index of relative abundance for nearshore reef fishes. Fisheries Research 81(1):89-93. https://doi.org/10.1016/j.fishres.2006.05.015
Hall-Arber, M., C. Pomeroy, and F. Conway. 2009. Figuring out the human dimensions of fisheries: illuminating models. Marine and Coastal Fisheries 1(1):300-314. https://doi.org/10.1577/ C09-006.1

Hangsleben, M. A., M. S. Allen, and D. Gwinn. 2013. Evaluation of electrofishing catch per unit effort for indexing fish abundance in Florida lakes. Transactions of the American Fisheries Society 142(1):247-256. https://doi.org/10.1080/00028487.2012.730106

Hansen, A. G. 2018. Coldwater lake and reservoir research projects. Annual Report, Colorado Parks and Wildlife, Fort Collins, Colorado, USA.

Harley, S. J., R. A. Myers, and A. Dunn. 2001. Is catch-per-uniteffort proportional to abundance? Canadian Journal of Fisheries and Aquatic Sciences 58(9):1760-1772. https://doi.org/10.1139/ $\underline{\mathrm{f} 01-112}$

Heymans, J. J., M. Coll, J. S. Link, S. Mackinson, J. Steenbeek, C. Walters, and V. Christensen. 2016. Best practice in Ecopath with Ecosim food-web models for ecosystem-based management. Ecological Modelling 331:173-184. https://doi.org/10.1016/j. ecolmodel.2015.12.007

Hilborn, R. 1985. Fleet dynamics and individual variation: why some people catch more fish than others. Canadian Journal of Fisheries and Aquatic Sciences 42:2-13. https://doi.org/10.1139/ f85-001

Hilborn, R., R. O. Amoroso, E. Bogazzi, O. P. Jensen, A. M. Parma, C. Szuwalski, and C. J. Walters. 2017. When does fishing forage species affect their predators? Fisheries Research 191:211-221. https://doi.org/10.1016/j.fishres.2017.01.008

Hornborg, S., I. van Putten, C. Novaglio, E. A. Fulton, J. L. Blanchard, É. Plagányi, C. Bulman, and K. Sainsbury. 2019. Ecosystem-based fisheries management requires broader performance indicators for the human dimension. Marine Policy 108:103639. https://doi.org/10.1016/j.marpol.2019.103639

Houle, J. E., K. H. Andersen, K. D. Farnsworth, and D. G. Reid. 2013. Emerging asymmetric interactions between forage and predator fisheries impose management trade-offs. Journal of Fish Biology 83(4):890-904. https://doi.org/10.1111/jfb.12163

Innes-Gold, A., M. Heinichen, K. Gorospe, C. Truesdale, J. Collie, and A. Humphries. 2020. Modeling 25 years of food web changes in Narragansett Bay as a tool for ecosystem-based management. Marine Ecology Progress Series 654:17-33. https:// doi.org/10.3354/meps13505

Johnston, R., M. Randson, E. Besedin, and E. Helm. 2006. What determines willingness to pay per fish? A meta-analysis of recreational fishing values. Marine Resource Economics 21 (1):1-32. https://doi.org/10.1086/mre.21.1.42629492

Kaemingk, M. A., K. L. Hurley, C. J. Chizinski, and K. L. Pope. 2020. Harvest-release decisions in recreational fisheries. Canadian Journal of Fisheries and Aquatic Sciences 77 (1):194-201. https://doi.org/10.1139/cjfas-2019-0119

Kimmerer, W., S. R. Avent, S. M. Bollens, F. Feyrer, L. F. Grimaldo, P. B. Moyle, M. Nobriga, and T. Visintainer. 2005. Variability in length-weight relationships used to estimate 
biomass of estuarine fish from survey data. Transactions of the American Fisheries Society 134(2):481-495. https://doi. org/10.1577/T04-042.1

Krebs, C. J. 2014. Estimation of survival rates. Pages 655-701 in Ecological methodology. Third edition, in prep. Addison-Wesley, Boston, Massachusetts, USA.

Kuffner, A. 2017. New approach urged for managing menhaden fishery. Providence Journal, 5 October.

Large, P. A. 1992. Use of a multiplicative model to estimate relative abundance from commercial CPUE data. ICES Journal of Marine Science 49(3):253-262. https://doi.org/10.1093/ icesjms/49.3.253

Levins, R. 1966. The strategy of model building in population biology. American Scientist 54(4):421-431.

Liu, J., T. Dietz, S. R. Carpenter, M. Alberti, C. Folke, E. Moran, A. N. Pell, P. Deadman, T. Kratz, J. Lubchenco, E. Ostrom, Z. Ouyang, W. Provencher, C. L. Redman, S. H. Schneider, and W. W. Taylor. 2007. Complexity of coupled human and natural systems. Science 317(5844):1513-1516. https://doi.org/10.1126/ science. 1144004

Lucy, J., and T. D. Holton. 1998. Release mortality in Virginia's recreational fishery for summer flounder, Paralichthys Dentatus. Marine Resource Report No. 97-8; VSG-97-09. Virginia Institute of Marine Science, College of William and Mary, Gloucester Point, Virginia, USA. https://doi.org/10.21220/m2-e77c-5m84

Macal, C. M., and M. J. North. 2005. Tutorial on agent-based modeling and simulation. Proceedings of the Winter Simulation Conference. Institute of Electrical and Electronics Engineers, Piscataway, New Jersey, USA. https://doi.org/10.1109/WSC.2005.1574234

Mackay, M., S. Yamazaki, J. M. Lyle, and E. M. Ogier. 2020. Determining management preferences in a multimethod consumptive recreational fishery. Ecology and Society 25(2):22. https://doi.org/10.5751/es-11602-250222

Malchoff, M. H., and J. A. Lucy. 1998. Short-term hooking mortality of summer flounder in New York and Virginia. Marine Resource Report No. 98-7. Virginia Institute of Marine Science, College of William and Mary, Gloucester Point, Virginia, USA. https://doi.org/10.21220/m2-mw7g-bj76

Martell, S. J. D., A. I. Beattie, C. J. Walters, T. Nayar, and R. Briese. 2002. Simulating fisheries management strategies in the Strait of Georgia ecosystem using Ecopath and Ecosim. Fisheries Centre Research Reports 10(2):16-23.

Martino, E. J., and E. D. Houde. 2012. Density-dependent regulation of year-class strength in age- 0 juvenile striped bass (Morone saxatilis). Canadian Journal of Fisheries and Aquatic Sciences 69(3):430-446. https://doi.org/10.1139/f2011-149

Mateo, I., E. G. Durbin, D. A. Bengtson, and D. Durant. 2011. Variations in growth of tautog in nursery areas in Narragansett Bay and Rhode Island coastal ponds. Marine and Coastal Fisheries 3(1):271-278. https://doi.org/10.1080/19425120.2011.601943

Matsumura, S., B. Beardmore, W. Haider, U. Dieckmann, and R. Arlinghaus. 2019. Ecological, angler, and spatial heterogeneity drive social and ecological outcomes in an integrated landscape model of freshwater recreational fisheries. Reviews in Fisheries Science \& Aquaculture 27(2):170-197. https://doi. org/10.1080/23308249.2018.1540549

Meng, L., C. D. Orphanides, and J. C. Powell. 2002. Use of a fish index to assess habitat quality in Narragansett Bay, Rhode Island. Transactions of the American Fisheries Society 131(4):731-742. https://doi.org/10.1577/1548-8659(2002)131<0731:UOAFIT>2.0. $\mathrm{CO}: 2$

Mercer, A., and T. Sproul. 2018. The economic impact of Rhode Island's fisheries and seafood. Commercial Fisheries Research Foundation, Kingston, Rhode Island, USA.

Morse, W. W. 1981. Reproduction of the summer flounder, Paralichthys dentatus (L.). Journal of Fish Biology 19(2):189-203. https://doi.org/10.1111/j.1095-8649.1981.tb05823.x

Muallil, R. N., R. C. Geronimo, D. Cleland, R. B. Cabral, M. V. Doctor, A. Cruz-Trinidad, and P. M. Aliño. 2011. Willingness to exit the artisanal fishery as a response to scenarios of declining catch or increasing monetary incentives. Fisheries Research 111 (1):74-81. https://doi.org/10.1016/j.fishres.2011.06.013

Narragansett Bay Estuary Program. 2017. The state of Narragansett Bay and its watershed. Technical Report. Narragansett Bay Estuary Program, Providence, Rhode Island, USA.

National Marine Fisheries Service. 2018. Fisheries economics of the United States Report, 2016. NOAA Tech. Memo. NMFS-F/ SPO-187:243. U.S. Dept. of Commerce, Washington, D.C., USA.

National Oceanic and Atmospheric Administration (NOAA) Fisheries. 2020a. Summer flounder. NOAA Fisheries, Washington, D.C., USA. NJ Division of Fish \& Wildlife, Trenton, New Jersey, USA. [online] URL: https://www.fisheries.noaa.gov/ species/summer-flounder

National Oceanic and Atmospheric Administration (NOAA) Fisheries. 2020b. Bluefish. NOAA Fisheries, Washington, D.C., USA. https://www.fisheries.noaa.gov/species/bluefish

National Oceanic and Atmospheric Administration (NOAA) Fisheries. 2020c. Atlantic striped bass. NOAA Fisheries, Washington, D.C., USA. https://www.fisheries.noaa.gov/species/ atlantic-striped-bass

Nelson, K. L. 1998. Catch-and-release mortality of striped bass in the Roanoke River, North Carolina. North American Journal of Fisheries Management 18(1):25-30. https://doi.org/10.1577/1548-8675 (1998)018<0025:CARMOS > 2.0.CO;2

New Jersey Division of Fish \& Wildlife. 2010. Striped bass length/ age frequency data. NJ Division of Fish \& Wildlife, Trenton, New Jersey, USA. [online] URL: https://www.state.nj.us/dep/fgw/ artstrpbass 10 pbsample.htm

Nixon, S. W., B. A. Buckley, S. L. Granger, L. A. Harris, A. J. Oczkowski, R. W. Fulweiler, and L. W. Cole. 2008. Nitrogen and phosphorus inputs to Narragansett Bay: past, present, and future. Pages 101-175 in A. Desbonnet and B. A. Costa-Pierce, editors. Science for ecosystem-based management: Narragansett Bay in 
the 21 st Century. Springer, New York, New York, USA. https:// doi.org/10.1007/978-0-387-35299-2_5

Nobriga, M. L., and F. Feyrer. 2008. Diet composition in San Francisco Estuary striped bass: does trophic adaptability have its limits? Environmental Biology of Fishes 83(4):495-503. https:// doi.org/10.1007/s10641-008-9376-0

Nolan, J., D. Parker, G. C. van Kooten, and T. Berger. 2009. An overview of computational modeling in agricultural and resource economics. Canadian Journal of Agricultural Economics/Revue canadienne d'agroeconomie 57(4):417-429. https://doi.org/10.1111/ j.1744-7976.2009.01163.x

Ono, K., A. Haynie, A. Hollowed, J. Ianelli, C. McGilliard, and A. Punt. 2017. Management strategy analysis for multispecies fisheries including technical interactions and human behavior in modeling management decisions and fishing. Canadian Journal of Fisheries and Aquatic Sciences 75(8):1185-1202. https://doi. org/10.1139/cjfas-2017-0135

Oviatt, C., S. Olsen, M. Andrews, J. Collie, T. Lynch, and K. Raposa. 2003. A century of fishing and fish fluctuations in Narragansett Bay. Reviews in Fisheries Science 11(3):221-242. https://doi.org/10.1080/10641260390244413

Oviatt, C., L. Smith, J. Krumholz, C. Coupland, H. Stoffel, A. Keller, M. C. McManus, and L. Reed. 2017. Managed nutrient reduction impacts on nutrient concentrations, water clarity, primary production, and hypoxia in a north temperate estuary. Estuarine, Coastal and Shelf Science 199:25-34. https://doi. org/10.1016/j.ecss.2017.09.026

Paloheimo, J. E., and L. M. Dickie. 1964. Abundance and fishing success. Rapports et Procès-verbaux des Réunions du Conseil International pour Exploration de la Mer 155:152-163.

Pascoe, S., T. Cannard, E. Jebreen, C. M. Dichmont, and J. Schirmer. 2015. Satisfaction with fishing and the desire to leave. Ambio 44(5):401-411. https://doi.org/10.1007/s13280-014-0579-7

Pauly, D., V. Christensen, and C. Walters. 2000. Ecopath, Ecosim, and Ecospace as tools for evaluating ecosystem impact of fisheries. ICES Journal of Marine Science 57(3):697-706. https:// doi.org/10.1006/jmsc. 2000.0726

Peterman, R. M., and G. J. Steer. 1981. Relation between sportfishing catchability coefficients and salmon abundance. Transactions of the American Fisheries Society 110(5):585-593. https://doi.org/10.1577/1548-8659(1981)110<585:RBSCCA $>2.0$. $\mathrm{CO} ; 2$

Pihl, L., S. P. Baden, R. J. Diaz, and L. C. Schaffner. 1992. Hypoxia-induced structural changes in the diet of bottomfeeding fish and Crustacea. Marine Biology 112(3):349-361. https://doi.org/10.1007/BF00356279

Pitman, K. J., S. M. Wilson, E. Sweeney-Bergen, P. Hirshfield, M. C. Beere, and J. W. Moore. 2019. Linking anglers, fish, and management in a catch-and-release steelhead trout fishery. Canadian Journal of Fisheries and Aquatic Sciences = Journal Canadien des Sciences Halieutiques et Aquatiques 76 (7):1060-1072. https://doi.org/10.1139/cjfas-2018-0080
Pollnac, R. B., and J. J. Poggie. 1991. Psychocultural adaptation and development policy for small-scale fishermen's cooperatives in Ecuador. Human Organization 50(1):43-49. https://doi. org/10.17730/humo.50.1.97tm3638277868n7

Polovina, J. J. 1984. Model of a coral reef ecosystem. Coral Reefs 3(1):1-11. https://doi.org/10.1007/BF00306135

Rhode Island DEM. 2020. Marine fisheries minimum sizes \& possession limits. Rhode Island DEM, Providence, Rhode Island, USA. [online] URL: http://www.dem.ri.gov/programs/marinefisheries/mfsizes.php

Richards, L. J., and J. T. Schnute. 1986. An experimental and statistical approach to the question: is CPUE an index of abundance? Canadian Journal of Fisheries and Aquatic Sciences 43(6):1214-1227. https://doi.org/10.1139/f86-151

Robillard, E., C. S. Reiss, and C. M. Jones. 2008. Reproductive biology of bluefish (Pomatomus saltatrix) along the East Coast of the United States. Fisheries Research 90(1-3):198-208. https:// doi.org/10.1016/j.fishres.2007.10.020

Schlüter, M., R. R. J. Mcallister, R. Arlinghaus, N. Bunnefeld, K. Eisenack, F. Hölker, E. J. Milner-Gulland, B. Müller, E. Nicholson, M. Quaas, and M. Stöven. 2012. New horizons for managing the environment: a review of coupled social-ecological systems modeling. Natural Resource Modeling 25(1):219-272. https://doi.org/10.1111/j.1939-7445.2011.00108.x

Shafer, J. L. 2007. Agent-based simulation of a recreational coral reef fishery: linking social and ecological dynamics. Dissertation, University of Hawai'i at Manoa, Hawai'i, USA.

Sharov, A., G. Nelson, H. Corbett, G. Wippelhauser, K. Sullivan, G. Shepherd, N. Lengyel, K. Gottschall, A. Kahnle, K. Hattala, K. McShane, and C. Hoffman. 2013. Striped bass stock assessment for 2013. Pages 492-967. 57th Northeast Regional Stock Assessment Workshop (57th SAW) assessment report. Northeast Fisheries Science Center, Woods Hole, Massachusetts, USA.

Smith, A. D. M., K. J. Sainsbury, and R. A. Stevens. 1999. Implementing effective fisheries-management systems management strategy evaluation and the Australian partnership approach. ICES Journal of Marine Science 56(6):967-979. https:// doi.org/10.1006/jmsc. 1999.0540

Southeast Data, Assessment, and Review (SEDAR). 2015. SEDAR 40 - Atlantic Menhaden Stock Assessment Report. SEDAR, North Charleston, South Carolina, USA.

Southeast Data, Assessment, and Review (SEDAR). 2020. Ecological reference points stock assessment report: Atlantic menhaden. SEDAR, North Charleston, South Carolina, USA.

Szczepanski, J. 2013. Feeding ecology of skates and rays in Delaware and Narragansett Bays. Dissertation. University of Rhode Island, Kingston, Rhode Island, USA. https://doi. org/10.23860/diss-szczepanski-john-2013

Terceiro, M. 2010. Stock assessment of summer flounder for 2010. NOAA Fisheries, Northeast Fisheries Science Center, Woods Hole, Massachusetts, USA. 
Tsuboi, J., and S. Endou. 2008. Relationships between catch per unit effort, catchability, and abundance based on actual measurements of salmonids in a mountain stream. Transactions of the American Fisheries Society 137(2):496-502. https://doi. org/10.1577/T06-259.1

van Poorten, B. T., C. J. Walters, and H. G. M. Ward. 2016. Predicting changes in the catchability coefficient through effort sorting as less skilled fishers exit the fishery during stock declines. Fisheries Research 183:379-384. https://doi.org/10.1016/j. fishres.2016.06.023

White, J. W., A. Rassweiler, J. F. Samhouri, A. C. Stier, and C. White. 2014. Ecologists should not use statistical significance tests to interpret simulation model results. Oikos 123(4):385-388. https://doi.org/10.1111/j.1600-0706.2013.01073.x

Wijermans, N., W. J. Boonstra, K. Orach, J. Hentati-Sundberg, and M. Schlüter. 2020. Behavioural diversity in fishing-towards a next generation of fishery models. Fish and Fisheries 21 (5):872-890. https://doi.org/10.1111/faf.12466

Wildenhain, E. 2016. Catchability of largemouth bass (Micropterus salmoides) on coarse woody habitat in a Northern USA temperate lake. Dissertation. University of Notre Dame Environmental Research Center, Land O'Lakes, Wisconsin, USA. [online] URL: https://underc.nd.edu/assets/215459/ fullsize/wildenhain2016.pdf

Wilensky, U. 1999. NetLogo. Center for Connected Learning and Computer-Based Modeling, Northwestern University, Evanson, Illinois, USA. 
Appendix 1. Supplementary material.

The equation used to convert instantaneous mortality to annual mortality:

$$
S=e^{-Z}
$$

Where $S$ is the annual survival and $Z$ is the instantaneous mortality (Gulland 1969).

The equation to convert annual mortality to weekly mortality:

$$
S_{w}=S^{\frac{1}{52}}
$$

Where $S_{w}$ is the weekly survival rate (Krebs 2017). 
Table A1.1. The age and size distribution used to convert piscivorous fish biomass $(\mathrm{g} / \mathrm{m} 2)$ to a number of fish (estimated from NJ Division of Fish \& Wildlife 2010, Sharov et al. 2013). Weight was estimated using a striped bass length-weight equation (Kimmerer et al. 2005).

\begin{tabular}{lccl}
\hline Age (years) & Length (inches) & Weight $(\mathbf{g})$ & Proportion of population \\
\hline 1 & 7.07 & 71.23 & 0.25 \\
2 & 12.86 & 460.46 & 0.22 \\
3 & 17.60 & 1225.58 & 0.18 \\
4 & 21.48 & 2282.08 & 0.15 \\
5 & 24.48 & 3509.48 & 0.1 \\
6 & 27.25 & 4798.87 & 0.05 \\
7 & 29.38 & 6068.37 & 0.025 \\
8 & 31.13 & 7263.93 & 0.015 \\
9 & 32.55 & 8354.56 & 0.002 \\
10 & 33.72 & 9326.35 & 0.002 \\
11 & 34.68 & 10177.01 & 0.002 \\
12 & 35.46 & 10911.55 & 0.002 \\
$13+$ & 36.10 & 11539.12 & 0.002 \\
\hline
\end{tabular}


Table A1.2. The power, linear, and static abundance-catch relationships used to represent the likelihood of catching a keeper or sublegal fish from shore or boat fishing methods, where $A$ represents abundance. Value sources for these equations can be found in the main text (see "Submodels" section).

\begin{tabular}{lcccc}
\hline Relationship & Keeper/Boat & Keeper/Shore & Sublegal/Boat & Sublegal/Shore \\
\hline Power & $0.04 A^{0.40}$ & $0.02 A^{0.23}$ & $0.08 A^{0.26}$ & $0.04 A^{0.25}$ \\
Linear & $0.0002 A$ & $0.00003 A$ & $0.00008 A$ & $0.00009 A$ \\
Static & 0.40 & 0.07 & 0.67 & 0.34 \\
\hline
\end{tabular}


Table A1.3. Forecasted biomasses $\left(\mathrm{g} / \mathrm{m}^{2}\right)$ for the six mid and upper trophic level functional groups at the year 2030 under the four scenarios of commercial forage fish harvest.

\begin{tabular}{lcccc} 
Functional Group & Zero $(\mathbf{F}=\mathbf{0})$ & Status Quo $(\mathbf{F}=\mathbf{0 . 2 0 2})$ & Intermediate $(\mathbf{F}=1.68)$ & Extreme $(\mathbf{F}=3.167)$ \\
\hline Forage Fish & 20.16 & 19.09 & 12.93 & 9.06 \\
Piscivorous Fish & 9.92 & 9.60 & 8.10 & 7.48 \\
Benthivorous Fish & 14.14 & 13.93 & 12.88 & 12.34 \\
Carnivorous Benthos & 12.74 & 12.75 & 12.73 & 12.63 \\
Large Squid & 1.15 & 1.12 & 0.93 & 0.80 \\
Small Squid & 0.96 & 0.91 & 0.64 & 0.52 \\
\hline
\end{tabular}


Fig. A1.1. Piscivorous fish biomass forecasts of the coupled social-ecological model for the four scenarios of commercial forage fish harvest compared to the food web (EwE) forecast. The different color lines represent the three variations of abundance-catch relationship in the socialecological model, and the black line represents the stand-alone food web forecast.
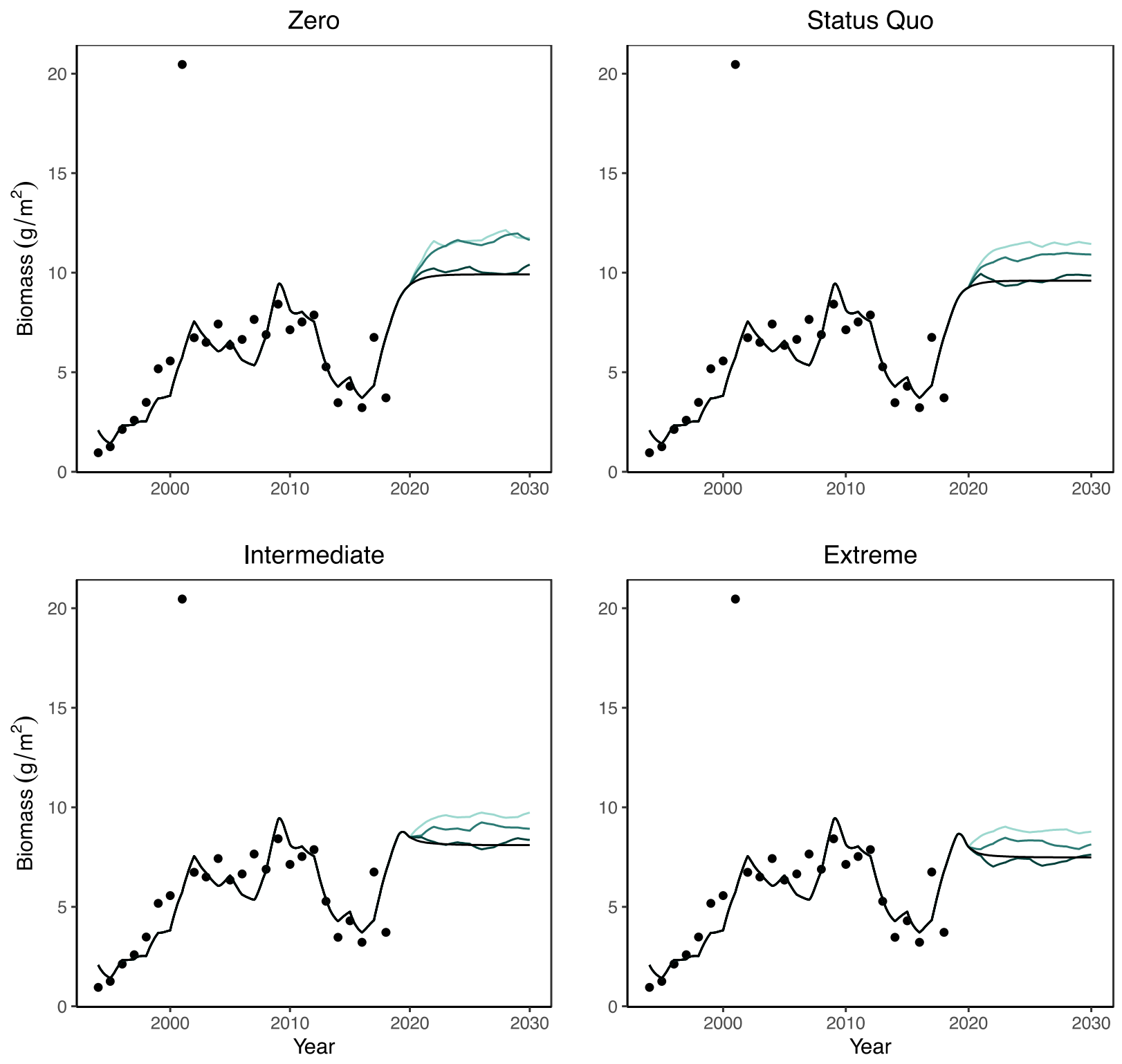

Forecast - ABM Linear - ABM Static - ABM Power - EwE 
Fig. A1.2. Piscivorous fish biomass forecasts of the coupled social-ecological model for the four scenarios of commercial forage fish harvest compared to the EwE forecast. The three different color lines are the variations of satisfaction loss rate in the social-ecological model, and the black line represents the stand-alone food web forecast.
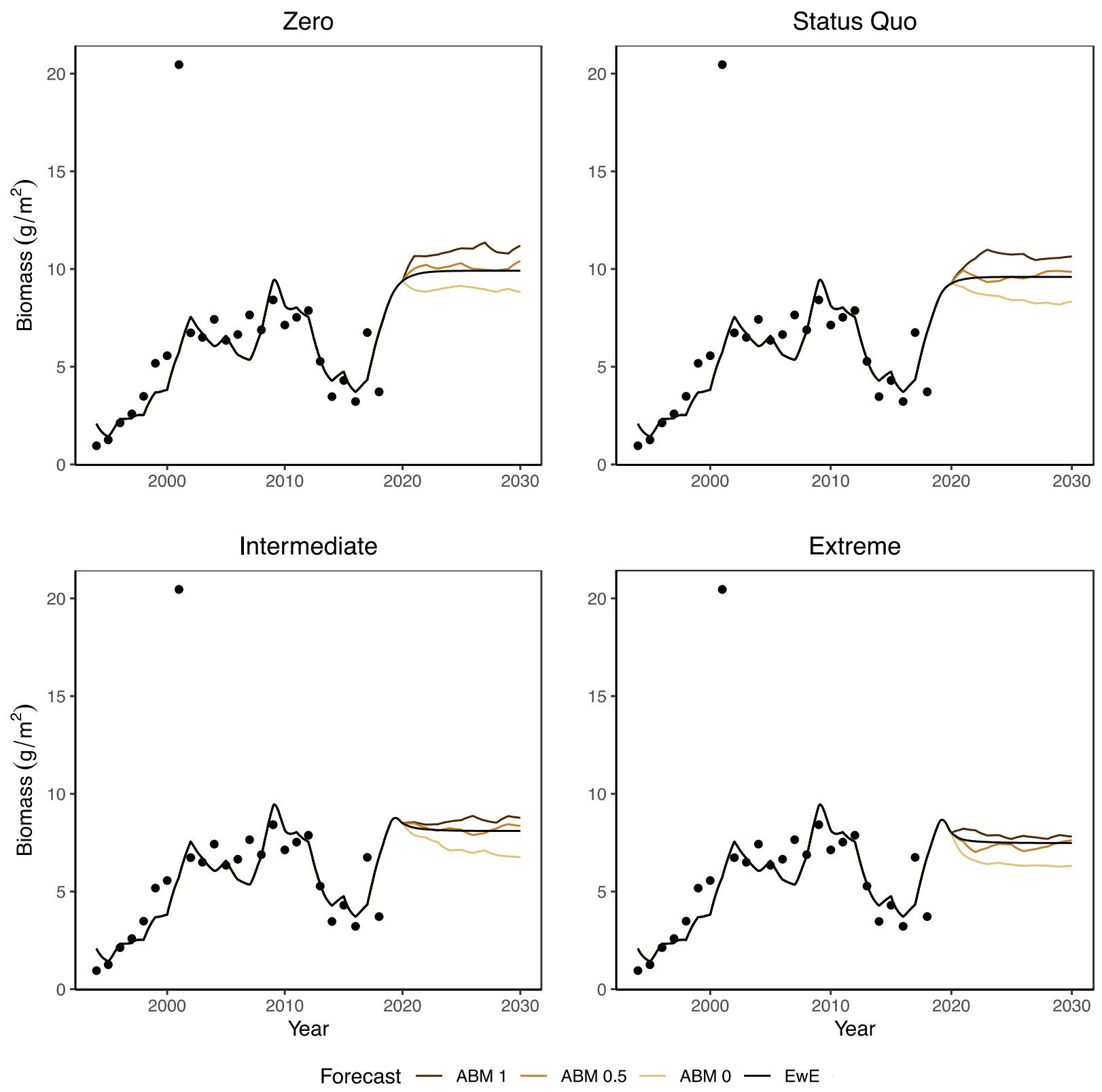
Literature Cited

Gulland, J. A. 1969. SECTION 5. MORTALITIES. Page Manual of Methods for Fish Stock Assessment - Part 1. Fish Population Analysis. Food and Agriculture Organization of the United Nations, Rome.

Kimmerer, W., S. R. Avent, S. M. Bollens, F. Feyrer, L. F. Grimaldo, P. B. Moyle, M. Nobriga, and T. Visintainer. 2005. Variability in Length-Weight Relationships Used to Estimate Biomass of Estuarine Fish from Survey Data. Transactions of the American Fisheries Society 134(2):481-495.

Krebs, C. J. 2017. Estimation of Survival Rates. Pages 655-701. Second edition.

NJ Division of Fish \& Wildlife. 2010. Striped Bass Length/Age Frequency Data. https://www.state.nj.us/dep/fgw/artstrpbass 10_pbsample.htm.

Sharov, A., G. Nelson, H. Corbett, G. Wippelhauser, K. Sullivan, G. Shepherd, N. Lengyel, K. Gottschall, A. Kahnle, K. Hattala, K. McShane, and C. Hoffman. 2013. Striped Bass Stock Assessment for 2013. Pages 492-967. 57th SAW Assessment Report, Atlantic States Marine Fisheries Commission. 